\title{
Habitat of Biodegraded Heavy Oils: Industrial Implications
}

\author{
R. Eschard and A.Y. Huc \\ Institut français du pétrole, IFP, 1-4 avenue de Bois-Préau, 92852 Rueil-Malmaison Cedex - France \\ e-mail: remi.eschard@ifp.fr - a-yves.huc@ifp.fr
}

\begin{abstract}
Résumé - Habitat géologique des huiles lourdes biodégradées : implications industrielles - Les huiles lourdes, extra-lourdes et les sables bitumineux représentent des ressources mondiales équivalentes à celles des pétroles conventionnels. En raison de leur forte viscosité leur production est un défi technique et économique majeur. Comprendre l'origine et l'habitat géologique de ces pétroles non-conventionnels est un enjeu important pour optimiser les opérations d'exploration et de production.

La grande majorité des pétroles lourds est le résultat de la dégradation de pétroles conventionnels par une activité bactérienne. Les facteurs limitant des processus biologiques impliqués (température, sels nutritifs, etc.) sont contrôlés par la situation géologique. De ce point de vue, les bassins d'avant-pays, qui abritent actuellement une large part des accumulations d'huiles lourdes, sont particulièrement favorables à la biodégradation de grandes charges d'huiles. En effet, ces bassins se caractérisent par une migration latérale des huiles sur de longues distances, drainant de ce fait un volume important du système pétrolier. Cette migration est favorisée par un système de drains efficaces présentant une grande continuité latérale. Ces derniers correspondent aux premiers remplissages sédimentaires, fluviaux et fluviaux-deltaïques, se mettant en place lors de l'initiation tectonique du bassin d'avant-pays. La structure du bassin permet ainsi aux huiles d'atteindre, au niveau du «fore bulge», des profondeurs suffisamment faibles pour que la température permette l'activité bactérienne. Les réservoirs associés avec le « fore bulge » sont souvent constitués de corps sableux non consolidés, car n'ayant jamais subis d'enfouissement notables, et présentant de fortes porosités et perméabilités. Avant d'être mis en charge, ils contiennent de larges volumes d'eau, et ils facilitent les circulations d'eaux météoriques, favorisant la disponibilité des sels nutritifs indispensables aux micro-organismes responsables de la biodégradation.

En ce qui concerne la production, les hétérogénéités associées aux corps sédimentaires fluviaux ou fluviaux-deltaïques doivent être attentivement pris en compte. Notamment, les modèles géologiques développés pour rendre compte de l'architecture et de l'évolution stratigraphique des chenaux fluviaux et des vallées incisées fournissent des guides utiles lorsqu'il s'agit de caractériser les réservoirs situés dans un tel contexte géologique afin de les produire.

Les difficultés techniques qu'il y a pour récupérer ces huiles très visqueuses exigent, à l'évidence, de disposer d'une description du réservoir encore plus détaillée que ce que requiert la production de pétrole conventionnel. Les réservoirs Crétacé de la Formation de Mannville au Canada sont donnés comme exemples des types d'hétérogénéités présents dans les corps sédimentaires fluviaux, du contrôle géologique de ces hétérogénéités, de leurs effets sur la récupération des huiles lourdes et de la prise en compte de l'information géologique dans la stratégie de production.
\end{abstract}




\begin{abstract}
Habitat of Biodegraded Heavy Oils: Industrial Implications - Heavy oil, extra-heavy oil and tar sands account for half of the petroleum resources of the world. Due to their high viscosity their production is a major technical and economical challenge. The understanding of the origin and geological habitat of these unconventional oils is crucial in order to optimize exploration and production operations.

The vast majority of these heavy oils originates from the biodegradation of conventional oils by bacterial activity. The limiting factors of the involved biological processes (temperature, nutrients, etc.) are controlled by the geological situation. In this respect, foreland basins which harbour a large part of the current deposits of heavy oils correspond to particularly favourable conditions in promoting the biodegradation of large charges of oil. They are characterized by long distance lateral oil migration draining substantial volume of the petroleum system. This migration is supported by an adequate drainage system which exhibits a large lateral continuity and consists of the first syntectonic fluvial and fluvial-deltaic sediments filling the foreland basins. As a result of this migration the oil reaches shallow situation in the forebulge where the temperature is compatible with bacterial activity. The reservoirs associated with the "forebulge" are often high porosity and high permeability sand bodies, initially hosting large volume of water and facilitating the circulation of meteoric water helping in the nutrient availability.

For the sake of production, the heterogeneities associated with these fluvial and fluvial-deltaic sediments have to be carefully considered. The geological models developed for the architecture and for the stratigraphic evolution of fluvial channels and incised valleys provide useful guidelines in order to characterize the reservoirs for production purposes in such geological setting. The technical difficulties in recovering these highly viscous fluids require to integrate more detailed reservoir description than usually needed when producing conventional oil plays. The Cretaceous reservoirs of the Mannville Formation in Canada is presented to exemplify the types of heterogeneities encountered in fluvial reservoirs, their rational, their effect on the heavy oil recovery and the impact of the geological knowledge on the production strategy.
\end{abstract}

\section{INTRODUCTION}

Conventional heavy oil, extra-heavy oil and bitumen represent a major technical and economical challenge for the future: their identified volumes in place are estimated to reach about $5000 \mathrm{Bb}$, that is to say the equivalent of the remaining resources in place of conventional oils discovered until now. It should be noted that about $56 \%$ of those resources are represented by bitumen in Canada and extra-heavy oils in Venezuela.

Only $1 \%$ of those heavy crude resources have already been produced. With current production technologies recoverable resources are estimated to $700 \mathrm{Bb}$. Oil and gas are the result of the natural thermal evolution and transformation of the sedimentary organic matter embedded in specific rocks: the socalled source rocks. Once generated, petroleum and gas are subsequently expulsed from this source rock and migrate throughout drainage pathways within porous/fractured permeable rocks (reservoir rocks) and along pervasive faults. On their way up towards the surface the migrating hydrocarbons are eventually trapped by "defaults" of the draining system associated with structural or sedimentological features. These local accumulations result in the formation of fields from which they can be eventually extracted by industrial means. During this upwards migration, from the generating source rock towards the surface, the hydrocarbons experiences a progressive decrease in temperature. If the oil reaches a sufficiently shallow depth with temperature liable to allow life to occur, a bacterial activity, feeding on petroleum, can develop and results in the alteration of the migrating and accumulating oil, promoting an increase of its viscosity.

In this respect, the vast majority of naturally occurring viscous to very viscous petroleum, coined as heavy oils and extra-heavy oils, or semi-solid petroleum material associated with sands (tar sands), are the products of the biological alteration of conventional fluid crude oils mediated by inreservoir bacterial communities. This is specifically true for the huge heavy oil resources of Western Canada and Eastern Venezuela. This phenomenon is known and described since the last mid-century (Winters and Williams, 1969; Evans et al., 1971; Deroo et al., 1977; Blanc and Connan, 1993; Head et al., 2003).

Such a biological alteration is potentially active as soon as the temperature of the geological environment hosting the oil is sufficiently low to allow the living processes of these microbial consortia to take place. Empirically, but based on a large set of observations, the microbial degradation of oil is assumed to be very active up to $65^{\circ} \mathrm{C}$, but to stay significant up to $80^{\circ} \mathrm{C}$. If we consider that the geothermal gradient can vary on a regional basis from $20^{\circ} \mathrm{C} / \mathrm{km}$ to $40^{\circ} \mathrm{C} / \mathrm{km}$, this corresponds to a maximum depth ranging from $1500 \mathrm{~m}$ to $3000 \mathrm{~m}$. 
Although quantitatively subordinate, it should be noted that other factors than biodegradation can be responsible for the formation of heavy oils. For instance, most of the heavy oils of California are explained by the very nature of the sedimentary organic matter from which the oil is sourced. This organic matter is thermally labile and releases petroleum at an early stage of the burial history of the source rock. This results in viscous, sulphur-rich, "thermally immature" oil (Isaacs and Rullkötter, 2000).

\section{BIO-GEOCHEMISTRY OF BIODEGRADATION}

\subsection{Implication on the Oil Composition}

The alteration by biodegradation of a "conventional oil" results in a compositional change producing progressively denser heavy oil. On a bulk molecular level the effects are well documented and are expressed by a quasi-sequential disappearance of specific classes of compounds: including successively the light hydrocarbons, the n-alkanes, the branched alkanes, the cyclic alkanes. Quasi-sequential expresses the fact that more resistant compounds classes can start to be altered prior to the complete destruction of a less resistant class and that a limited overlapping is possible (Peters et al., 2005). This progressive removal of light hydrocarbons and saturates implies an increase of the relative concentration of the remaining high molecular weight aromatics and NSO compounds (so-called resins and asphaltenes).

The industrial and economic implications of the biodegradation of oil are far reaching and include an increase of the viscosity, a decrease of the API gravity (Fig. 1), a relative increase of the metals content (i.e. $\mathrm{Ni}$ and $\mathrm{V}$, since they are mainly present within the NSO fraction being concentrated), and an increase of the sulphur content. Moreover the degradation of hydrocarbons by bacteria implies the formation of intermediate chemical species including acid compounds which result in an increase of the oil acidity. This is reflected by the usually high TAN values measured on biodegraded heavy oils (TAN: Total Acid Number, as determined in the laboratory, is the quantity of $\mathrm{KOH}$, in $\mathrm{mg}$, needed to neutralize $1 \mathrm{~g}$ of oil).

It should be noted that the increase in high molecular weigh fractions is probably not only the result of a relative concentration alone, following the selective removal of alkanes and to lesser extent of aromatics. Numerous evidences point to the fact that newly formed high molecular weight NSO compounds result from the biodegradation process (through oxidative reactions involving oxygen and sulphur species). In this respect and based on sulphur isotope consideration, the observed increase in sulphur content is, pro parte, the result of the incorporation of additional sulphur. The latter is probably associated with microbial sulphatereduction reactions, sustained by the sulphates when present in the formation water.

\subsection{Assessing the Level of Biodegradation}

The selective and quasi-sequential removal of hydrocarbon classes during the process of microbial alteration is routinely used for evaluating the extent of biodegradation of crude oils. On this basis Peters and Moldowan (Peters et al., 2005) have proposed a scale ranging from 1 to 10 , ranking the biodegradation level from none (0), light (1-3), moderate (4-5), heavy (6-7), very heavy (8-9) to severe (10). Similarly, the relative resistance of the branched alkanes compared to the n-alkanes is often accounted for by a convenient biodegradation parameter expresses as the following ratio: $n-\mathrm{C}_{17} /$ Pristane (Fig. 1). In this ratio, $\mathrm{nC}_{17}$ is a representative molecule of the n-alkanes, the most labile series as far as biodegradation alteration is concerned, and pristane $(2,6,10,14$ tetramethylpentadecane) a $\mathrm{C}_{19}$ branched alkane belonging to the isoprenoids family, molecules with a methyl group on every fourth carbon atom, exhibiting a more resistant behaviour to biodegradation.

\subsection{Quantitative Aspect of the Biodegradation of Oil}

Besides a substantial change in the properties of the petroleum, the biodegradation alteration is actually responsible for the destruction of a sizable amount of the initial oil. It should be noted for instance that mass balance calculations suggest that biodegraded oils ranking " 2 " on the "Peters and Moldowan scale" have experienced a mass loss of $30-40 \%$ of the non-degraded oil, and biodegraded oils ranking " 5 " a loss of up to $70 \%$ (Peters et al., 2005; Kowalewski et al., in press). With respect to these figures, it is noticeable to consider that the current resources of heavy oils, extra-heavy oils and tar sands represent half of the current total resources of petroleum on Earth. This altered petroleum being the remaining part left by the biodegradation process, we can speculate that the amount of initial resources of oil which have been altered stood for twice of the current resources of conventional oils.

The ultimate product of biodegradation being $\mathrm{CO}_{2}$, the quantitative input of this gas into the natural system needs to be considered in any realistic carbon cycle assessment, at a time scale still to be accurately defined.

\subsection{The Agents of Deep Subsurface Biodegradation}

In the recent years, a major advance has been achieved by identifying anaerobic organisms as the main (probably the only) agents of the biodegradation process in the deep subsurface. For years, the paradigm was that only aerobes were involved in the biodegradation of oils, or at least that anaerobes require aerobes to initiate degradation of petroleum (Jobson et al., 1979). This was based on a lack of knowledge in microbiology (the only known bacteria able to degrade hydrocarbon were aerobes) and on observations reporting 
that biodegraded oils fields were often associated with active meteoric waters. The meteoric waters were supposed to carry the necessary dissolved oxygen and accompanying aerobes, charged at the outcrops, into the subsurface. The modern view, emphasizing the role of anaerobes, relies on:

- Mass balance calculation showing that the quantity of dissolved oxygen brought in by the aquifers, even in the case of a very active aquifer, is largely insufficient to account for the degradation of a normal size oil pool (Horstad et al., 1992);

- The actual identification of anaerobic microbial communities in formation waters associated with biodegraded fields, and sampled under careful microbiologists conditions (Magot et al., 2000);

- The occurrence of biodegraded oil pools setting in geological situations where meteoritic water influx is unlikely (i.e. in certain deep offshore accumulations);

- The discovery of strains of anaerobic microorganisms able to degraded saturated and aromatic hydrocarbons (Widdel and Rabus, 2001);

- The isolation, from biodegraded oils of metabolites indicative of anaerobic hydrocarbon degradation (Aitken et al., 2004).

This new insight has considerable implications regarding the understanding of the biodegradation process and more importantly regarding the geological settings in which biodegraded oil fields can be discovered. The occurrence of a meteoric circulation is no more mandatory and consequently the biodegradation can potentially proceed in any hydrodynamic situation.

\subsection{The Limiting Factors}

It has been recognized for decades (Winters and Williams, $1969)$ that the main control on biodegradation is temperature (Fig. 1). As a matter of fact, in order to proceed this phenomenon requires that the environmental conditions are compatible with physiological processes. Although the theoretical limit of life is estimated to range between $120^{\circ} \mathrm{C}$ and $150^{\circ} \mathrm{C}$ (a strain living at $121^{\circ} \mathrm{C}$ has been recently identified), it seems that the maximum temperature for biodegradation in the deep subsurface is around $80^{\circ} \mathrm{C}$, but really effective up to $65-70^{\circ} \mathrm{C}$, and that beyond $90^{\circ} \mathrm{C}$ the oil fields are "sterilized".

The difference between the high theoretical values and the observation in the subsurface has been discussed by Head et $a l$. (2003) and tentatively explained by the low level of metabolic activity of the microorganisms living in the deep biosphere. This low metabolic rate is suspected to prevent the bacteria to renew at a sufficient rate their heat labile cell components and consequently to strongly lower the temperature limits allowing subterranean life.

A second important limiting factor is the availability of inorganic nutrients (i.e. phosphorus and potassium) in an environment strongly depleted in such elements. The main

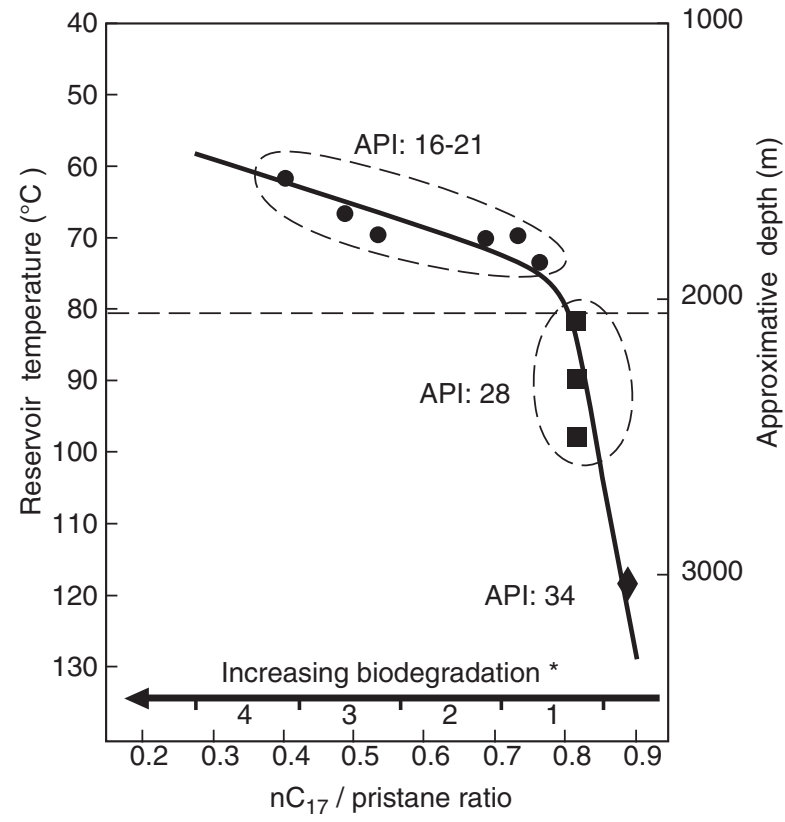

Figure 1

Change in the ratio $\mathrm{nC}_{17} /$ Pristane, as a proxy for the biodegradation extent, with reservoir temperature. Derived and modified from the Alba fields trend in the Outer Witch Ground Graben, UK (Mason et al., 1995). Relationships with API gravity values. Relationships with the Peters and Moldowan ranking scale* (Peters et al., 2005).

source for these nutrients is probably the dissolution of minerals by the formation water, probably enhanced by the microbial activity itself (Bennett et al., 2000). This is a slow process, which is likely to explain the low rate of biodegradation observed in petroleum reservoirs. A figure of $10^{-4} \mathrm{~kg}$ of degraded hydrocarbons $\mathrm{m}^{-3} \mathrm{yr}^{-1}$ at $40-70^{\circ} \mathrm{C}$ has been proposed (Head et al., 2003). In this respect the observation that biodegradation is often associated with the invasion of surface-derived meteoric formation waters can be explained by the fact that these low salinity waters are under-saturated for numerous inorganic chemical species and are consequently more aggressive to release nutrients by dissolution of minerals. This favoured availability of nutrients is likely to promote the metabolic rate of the in situ microbial communities. To some extent this would reconcile the new paradigm, according to which the occurrence of active meteoric water is not mandatory for biodegradation, with the empirically observed relationships between biodegradation and meteoric water influx.

\section{GEOLOGICAL CONTROLS}

Due to the external hydrophilic properties of their membrane bacteria are living in water. Moreover in order for them to 
have access to a sufficient supply of nutrients this water should exhibit a continuous fluid phase. In this respect the most favourable setting for biodegradation to proceed is at the base of the oil column, at the lower part of the oil-water transition zone (generically called the oil-water contact). Consequently a crucial control on the biodegradation efficiency is most probably the residence time of the hydrocarbon molecules at this oil-water contact. In this respect, if we consider that the new coming oil molecules reaching the reservoir, after migration from the source rock, are incorporated into the field at the oil-water contact, the biodegradation is likely to be concomitant with the filling of the reservoir. If this assumption held true, the filling conditions of a given field would be of paramount importance as far as biodegradation is concerned. This importance is comforted by the fact that the rate of biodegradation is estimated to be in a same order of magnitude than the rate of oil charging of a reservoir (Head et al., 2003). In such a dynamic system, the size, the shape, the sedimentary architecture of the reservoir and the in-filling rate will directly control the surface area, the pattern and the rate of displacement of the oil-water contact surface and consequently the exposure time to biodegradation of the fresh oil components arriving at the oil-water interface. The larger the oil-water contact surface and the lower the charging rate are, the more favourable the conditions would be for the effective biodegradation of an oil accumulation. On the other hand smaller oil-water contact surface and higher charging rate would prevent the biodegradation to proceed efficiently. This difference in the dynamic of oil charging might explain the variable level of biodegradation for fields with apparently the same temperature conditions and for which a similar composition would have been expected.

In a given reservoir the bacterial communities are suspected to be autochthonous. Which means that in the instance that the microbial population is killed by a sufficiently high temperature the replenishment by fresh bacteria is unlikely. In this respect, if during its geological history a reservoir experiences such a temperature before the oil in-filling takes place there is little chance that biodegradation can proceed, even if the current reservoir temperature would allow this phenomenon to occur. This is the case of reservoirs buried to temperature higher than $90^{\circ} \mathrm{C}$ before been uplifted and filled by oil. This sterilization process prior to oil charging is termed "paleo-pasteurisation", leading to unaltered petroleum in currently low temperature reservoirs, (Wilhelms et al., 2000). In the specific situation of multi-charged reservoir, the oil accumulation can eventually be successively fed before and after the sterilization event. This is suggested to be the origin of "mixed oils" exhibiting both the characters of biodegraded oil and of unaltered oil.

Reconstructing the temperature history of a target reservoir and the timing of oil charging, using basin modelling, is consequently of prime importance for explorationists to predict oil quality.
A point which is often overlooked when designing a production strategy is the possible occurrence of heterogeneities in the distribution of fluid properties. Oil charging history and conditions of biodegradation have the potential to impact the distribution of viscosity and API gravity in oilfields. For instance large-scale lateral and small-scale vertical variations in fluid properties are common within a reservoir (Larter $e t$ al., 2006). Due to the crucial importance of the oil viscosity in recovery operation of heavy oils, recognizing, or predicting these heterogeneities should be routinely included in the work flow of the reservoir characterization procedure.

\section{GEOLOGICAL HABITAT}

From a regional geology perspective, the heavy oils and tar sands are often associated with foreland basins (Fig. 2), i.e. Rocky Mountain foreland in Western Canada, Caribbean foreland in Eastern Venezuela (Tissot and Welte, 1984), Persian foreland in Iran (Bashari, 1988), Saudi Arabia and Kuwait (Wani and Al-Kabli, 2005), Florida-Cuba foreland basin (Magnier et al., 2004), the Junggar basin in China (Niu and $\mathrm{Hu}, 1999)$, the Adriatic depression in Albania and Italia (Roure et al., 2004). A foreland basin develops ahead of a mountain belt during its uplift. Sediments, which are eroded from the mountain belt, are deeply buried just ahead of the front belt in the foredeep part of the basin (Fig. 2). The sediments then progressively reach the surface away from the mountain belt in the forebulge area.

It is specifically in the forebulge area that the two major provinces of heavy oils i.e. Western Canada and Eastern Venezuela are found (Tissot and Welte, 1984). These wedge shape basins are the result of the regional loading of the sedimentary pile by the compressive mountain building which, through erosion, concomitantly acts as the main provider for the sediments deposited at the front of the growing range. The source rocks deposited in the passive margin sequences preceding the compressive episode or, latter, in the depression formed at the front of the orogenic belt are deeply buried in the foredeep during the process of mountain building. Consequently they reached adequate temperature conditions for oil generation, resulting in the formation of conventional oil fields after short distance oil migration. However, a common feature of such sedimentary basins is to exhibit a gentle dipping monoclinal pattern along the distal (from the mountain range) flank. This pattern is often accompanied by a lateral continuity of the reservoir bodies overlying the major basal unconformity of the foreland basin. This situation allows lateral migration of the fluids from the oil kitchen in the foredeep towards the forebulge. The drainage system exhibits a large lateral continuity and consists of the first syntectonic fluvial and deltaic sediments filling the foreland basins. These sediments onlap the basal major unconformity marking the beginning of the deformation in the foreland 


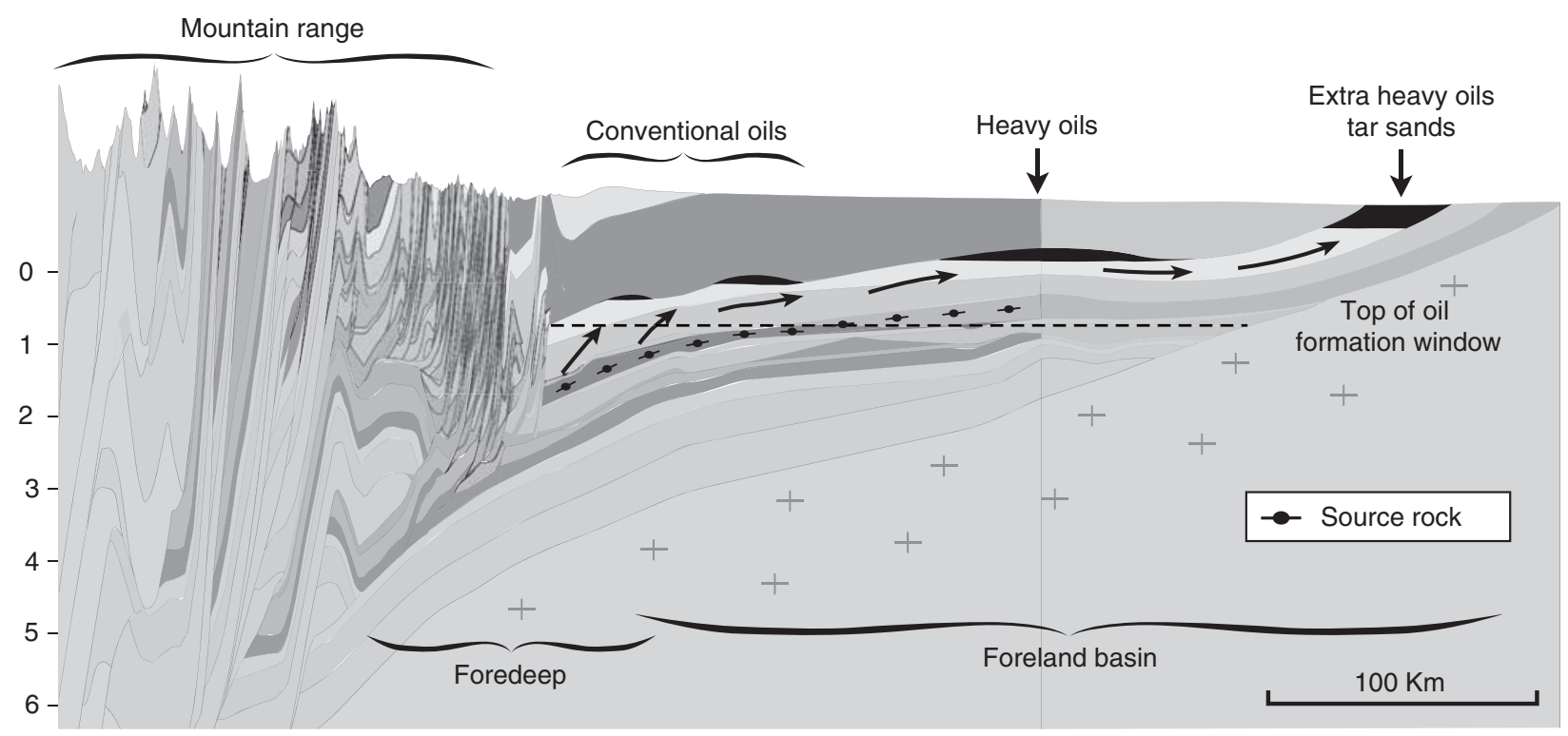

Figure 2

Schematic cross-section of a foreland basin providing a favourable geological situation for the formation of heavy oil accumulation. The world major heavy oil provinces such as the Alberta province in Canada and the northern Venezuela are located in similar settings (modified after Deroo et al., 1977; Demaison and Huizinga, 1994; Head et al., 2003)

basin. The sediment supply is both the result of the uplift of the thrust belts, and of the erosion of the growing forebulge. These continuous sedimentary layers act as efficient conductors for the migrating fluids. Subsequently the oil which is not trapped in intermediate accumulations, on its way up towards the far end of the basin, can proceed over long distance (up to hundred kilometres), and consequently corresponds to the drainage of sizeable volume of the petroleum system (Demaison and Huizinga, 1997).

Eventually the oil will reach the forebulge setting where depths become progressively shallower (Demaison, 1977) and enter a temperature regime where life can be sustained and which becomes increasingly favourable to bacterial activity. Subsequently along the migration pathway hydrocarbons will experience a step by step biodegradation, resulting in oils becoming heavier when approaching the shallow rim of the basin. Both the Western Canada and the Eastern Venezuela display such a geological situation. Moreover in these basins, the reservoirs located in the forebulge have never been buried during the whole history of the basin. As a consequence they correspond mainly to unconsolidated sands with a very high porosity and permeability.

A situation which is likely to favour biodegradation due to the large amount of water, with its associated load of nutrients, occurring in the porosity prior to filling, and its petro-physical properties prone to efficient hydrodynamism.

The normal crude oils produced from the Early Cretaceous reservoirs of the Western Canada basin are characterized by medium-high API gravity in the vicinity of the foredeep (i.e. $20-30^{\circ} \mathrm{API}$ in Bellshil lake area). Closer to the outcrops the Lloydminster and Peace River area contains heavy oil (15-20 API), then the Cold Lake and Wabasca deposits reaches $11^{\circ} \mathrm{API}$. Finally, the outcropping Athabasca sands (tar sands) contain extra-heavy oil (6-8 $\mathrm{API}$ ).

In Eastern Venezuela, the oils located at depths greater than $1500 \mathrm{~m}$ are medium to light $\left(25-40^{\circ} \mathrm{API}\right)$, low sulphur crudes (less than $1 \%$ S) (i.e. in the Officina area). When approaching the southern rim of the basin, the oils become progressively shallower, heavier and biodegraded (10-25 API) and richer in sulphur (1-3\% S) (i.e. in the Treblandor/Pilon areas). Finally they grade into the Orinoco Heavy Oil belt, a gigantic accumulation of sulphur-rich (4-5\% S) extra-heavy oil (less than $\left.10^{\circ} \mathrm{API}\right)$.

In foreland basins, some heavy oil plays can be also found in a more deeper and proximal situation. Following the generation of hydrocarbons in the foredeep and the migration and trapping of the oil in reservoirs located at shallow depth over the forebulge where biodegradation is extensive, the progress of the deformation front implies the migration of the foreland basin and consequently the potential burial of the reservoir units and eventual involvement in the deformed zone. This is for example the case for the heavy oil-bearing fracturated carbonate reservoirs in Iran (Bashari, 1988) or in Cuba (Magnier et al., 2001). These currently buried accumulations, occurring just below the basal unconformity, are interpreted as having being charged and biodegraded while at shallow depth in a forebulge situation (Fig. 3). 


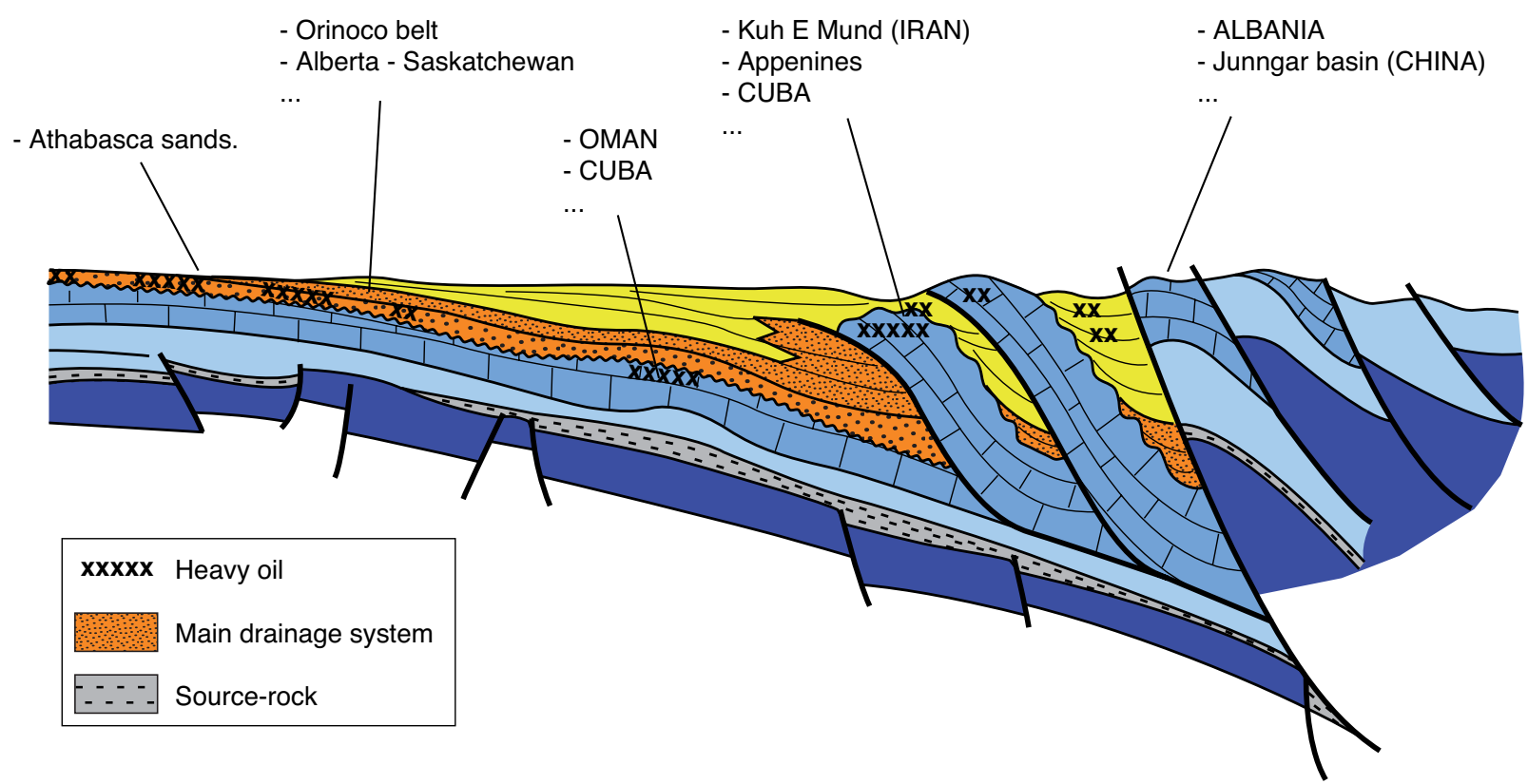

Figure 3

Types of habitat of heavy oil fields in foreland basins. The oil migrated from the fore deep to the fore bulge through fluvial sands on lapping the foreland basal unconformity. Biodegradation occurs at shallow depth. Reservoir may have been latterly buried in the foreland itself or uplifted in the thrust belt with their heavy oil charges. Reservoirs either consist of fluvio-deltaic clastic sediments belonging to the synorogenic succession, or of the carbonates belonging to the ante-orogenic series.

Although of lesser occurrence, heavy oil can be found in fluvial and deltaic synorogeic sediments reservoir in the thrust belt itself (Fig. 3). This is for example the case in the Miocene of the Patos-Marinze field in Albania (Roure et al., 2004) or in the Junggar basin in China (Niu and Hu, 1999). The oil is interpreted to have dismigrated vertically along the faults and throughout the synorogenic sediments. Biodegradation was then active when reaching the near surface conditions, eventually forming a plug at the exposure, trapping lighter hydrocarbons down dip.

Although of much less extend in term of global resources, deep offshore old passive margin correspond to another economically important habitat of heavy oils, as exemplified by Brazil (Capeleiro et al., 2001), West Africa or the Tertiary post-rift turbidites of North Sea (Jayasekera and Goodyear, 2000). These reservoirs usually occur at relatively shallow burial depth in a thermal context associated with a low heat flow; moreover in deep offshore the temperature at the mud line is low. As a result of this cooler temperature the entire underlying sedimentary column remains at a lower temperature than it would in onshore or shallow water at the same drill depths. This thermal situation which allows for bacterial activity to proceed at greater depth substantially increases the risk of biodegradation in deep water setting. Anaerobic biodegradation probably occurs here, as the connection with a fresh water aquifer is unlikely in the deep offshore geological context. It is interesting to note that the biodegraded fields described in this context again correspond to reservoir with limited burial, exhibiting coarse sands, with porosity and permeability preserved from compaction, belonging to turbiditic channels and lobes deposited in deep offshore environments (Fig. 4).

These habitats are not exclusive and various geological settings can harbour biodegraded heavy oils. However, by far, they are subordinate in term of resources.

Heavy oils are documented in rift systems which were latterly uplifted and even exhumed during the geological history. In the Majunga basin associated with the Madagascar western rift margin, the Bemolonga tar sands accumulation is trapped in Permo-triassic Karoo reservoirs and exposed at the surface (Jeans et al., 2006). The Permian and Mesozoic rift and post-rift successions were uplifted from the late Cretaceous, and the margin was tilted westwards then eroded in the hinterland. The heavy oil prospects probably result from the up dip migration of the oil following the main tilt, the oil being biodegraded when it approached the surface (Peter et al., 2006).

Continental rifts, pull apart and back-arc basins can also harbour heavy oil deposits. In such highly faulted settings the sediment supply and subsidence can be very high and the 


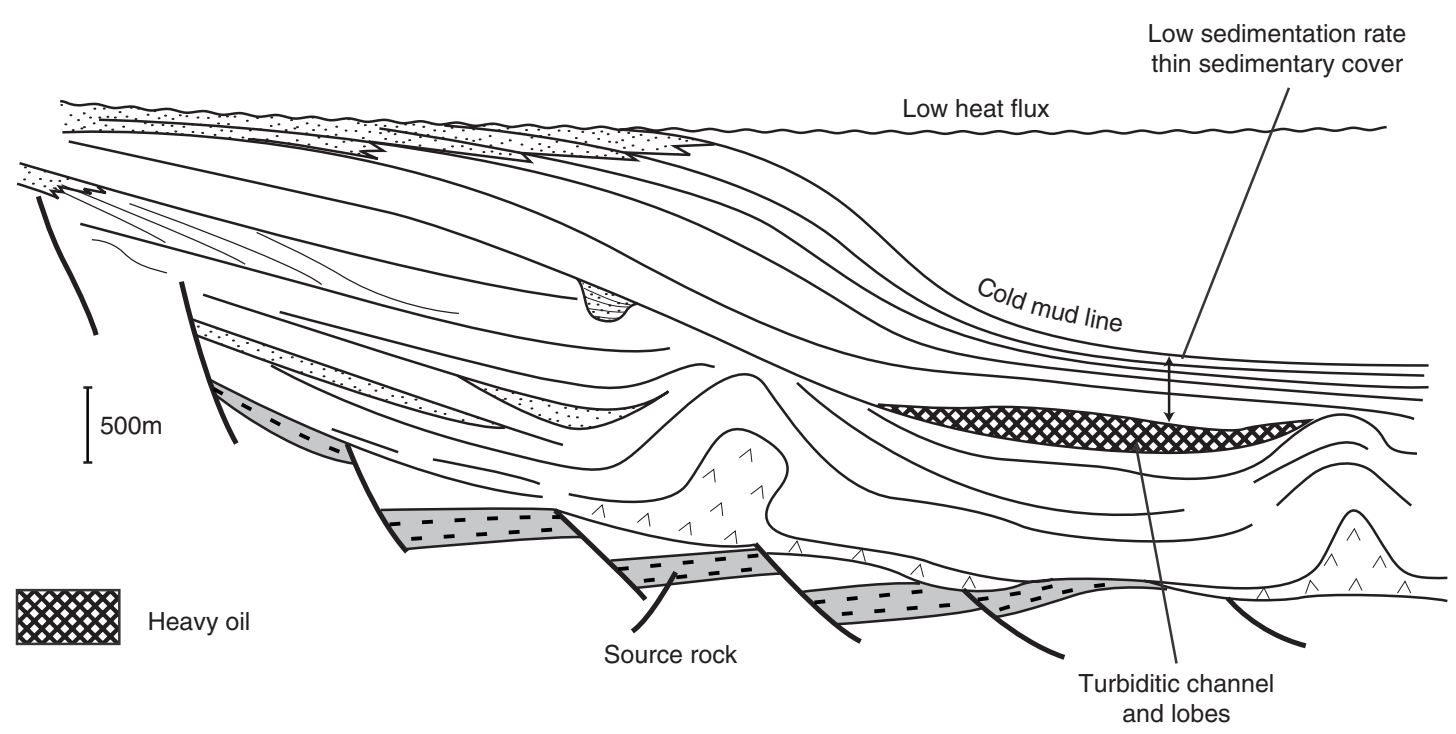

Figure 4

Types of habitat of the main heavy oil fields in old passive margin context: an early migration occurred in the turbiditic reservoir in a context where sedimentation rate and thermal conditions favour biodegradation processes.

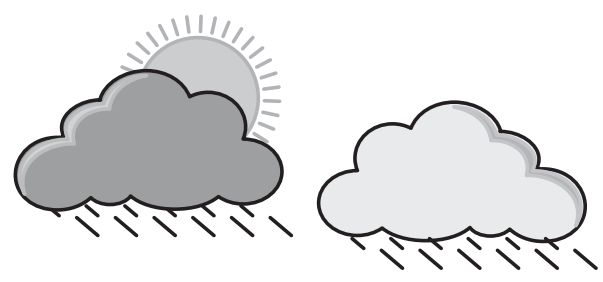

Meteoric weathering

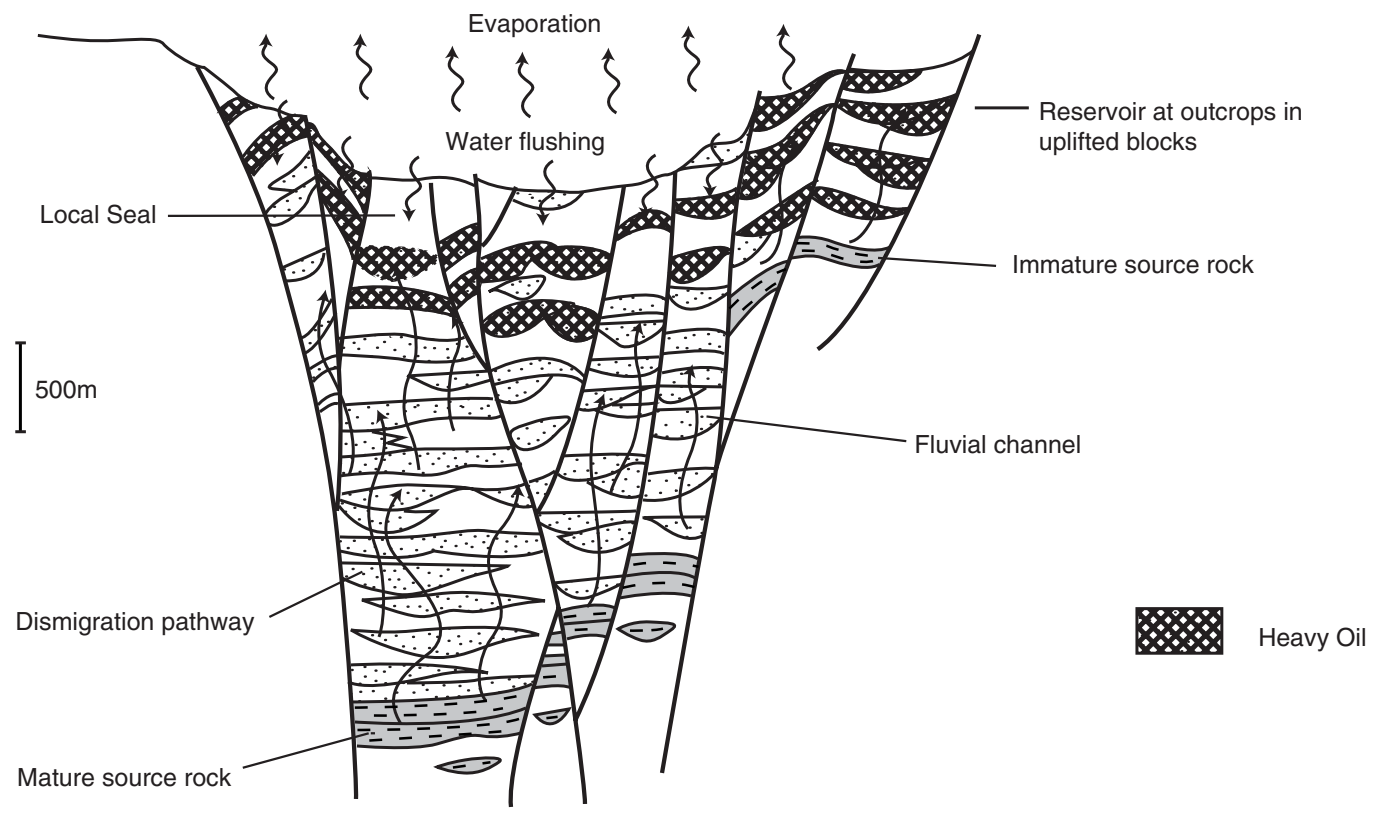

Figure 5

Types of habitat of the main heavy oil fields in pull apart or back arc basin filled by clastic sediments, with high subsidence rates. Dismigration occurred from the deep basin towards shallow horizons where the oil was degraded. 


\section{D:2001-04}

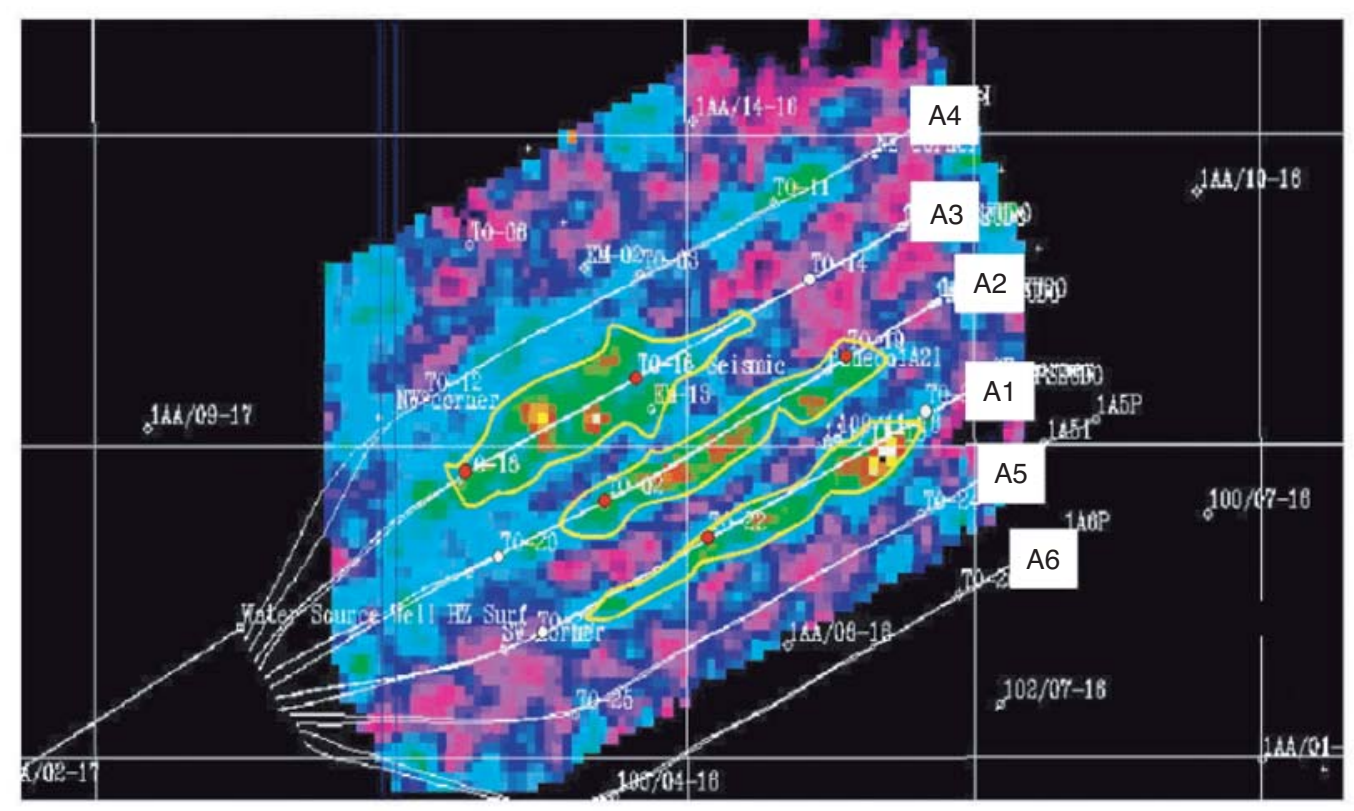

a)

\section{D:2001-05}

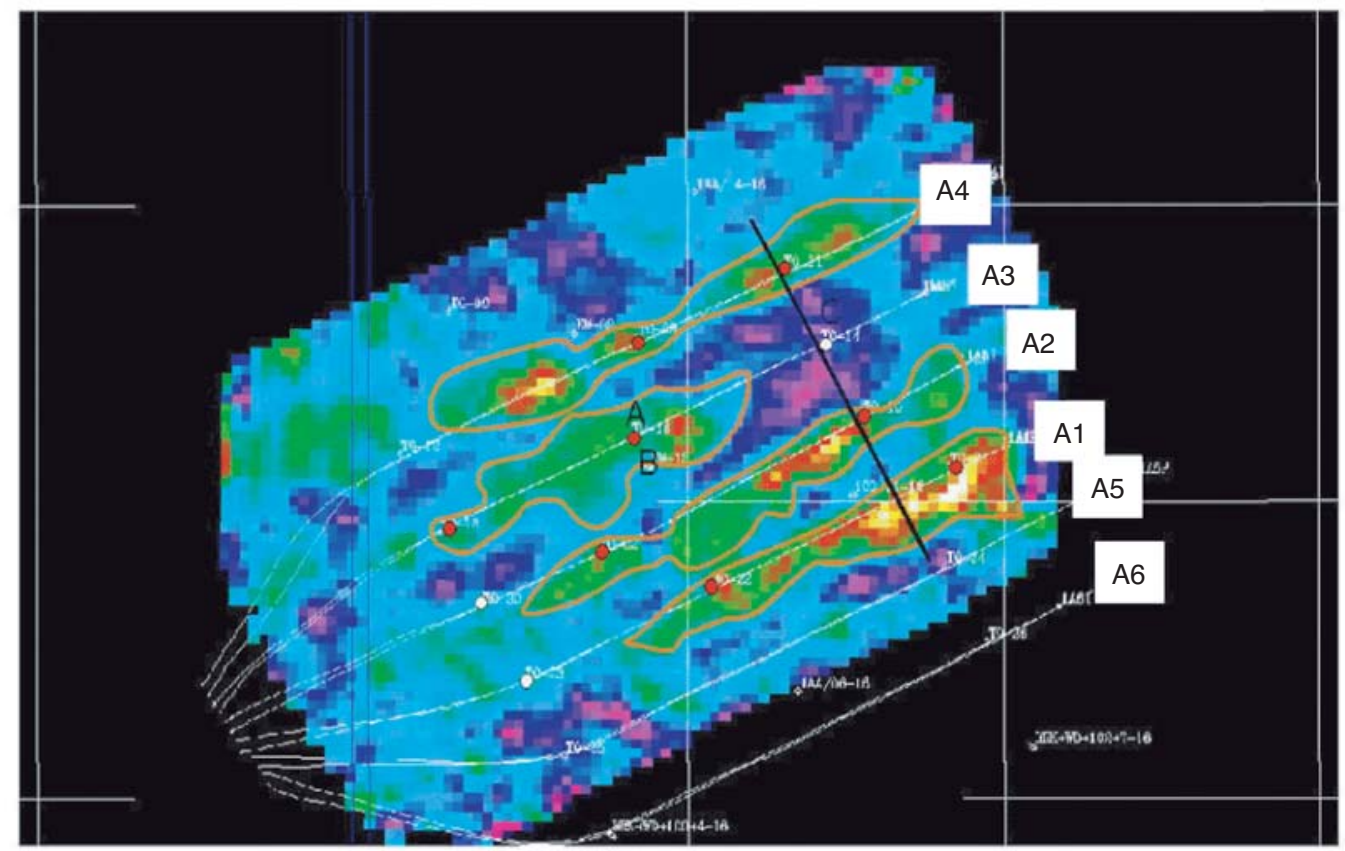

b)

Figure 6

Map view of 4D seismic amplitude differences between 2001 and 2004 (a) and 2001 and 2005 (b) in SAGD well pairs, Christina Lake field, Alberta. Observe for example the development of the steam chamber in the A4 well pair between the two surveys, from Zhang et al. (2005). 
basin-fill is mostly made of sand-rich fluvial sediments in which the seal efficiency is limited and the sand connectivity high. The oil migrated vertically through the clastic reservoirs or through the faults from the source rock to the surface. The oil can be finally trapped at shallow depth in compartments below a local seal or even reach the surface, where biodegradation process can proceed (Fig. 5). This situation is exemplified by the pull apart basins of California (Williams et al., 2001), or by the back-arc basins of Indonesia (Waite et al., 1997).

\section{SPECIFICITY OF HEAVY OIL RESERVOIR GEOLOGY, IMPACT ON PRODUCTION}

\subsection{Reservoir Workflow in Heavy Oil Fields and Reservoir Properties}

In heavy oil reservoirs, the high viscosity of the fluid hinders its displacement during cold production or enhanced production. Generally speaking, the drainage efficiency of a well is limited and rarely exceeds a few hundreds of meters at maximum. As examples, in the Kern River field in California, the typical steam injection pattern is a 5 spot covering 1 ha ( 2.5 acres) and in the Duri field in Indonesia, the injection pattern covers an area of around 6.25 ha (15.5 acres) (Curtis et al., 2002).

The reservoir modelling workflow which is used for developing heavy oil fields is strongly dependant on the depth of the prospect and on economic factors. Many shallow prospects are developed with wells without using any seismic data because the cost of seismic acquisition is higher than the cost to drill a cluster of shallow wells. As the reservoirs are getting deeper, well costs increase and well spacing will also be greater. The interpretation of the seismic data there becomes critical to predict reservoir extension and its properties between the wells. The reservoir workflow is also driven by economic factors. In the case of small fields with limited reserves, numerical models are rarely used, the reservoir being managed with conventional reservoir engineering techniques. When significant reserves are expected, the reservoir development workflow of an heavy oil reservoir developed by cold production methods would follow the classical steps of a reservoir simulation. After the description of the wells and the interpretation of seismic data, a reservoir layering is proposed taking into account specific porosity/permeability cut-offs (see section below). When available, 3D seismic data can be interpreted to extract some geological information used to constrain the reservoir model (Dequirez et al., 1995). The model is also carefully informed with fluid properties, saturation and viscosity variations being critical. Gridded numerical reservoir models are then built to better manage a long-term development of the reservoir: test of different recovery processes, optimization of well spacing, production forecasts, etc. (Svanes et al., 2004).
When thermal recovery processes are used, a 4D seismic monitoring approach can also be implemented to image the evolution of the steam chamber. The steam chamber development modifies the petro-acoustic properties of the reservoir because of the phase changes, the pressure increase and the oil saturation and viscosity variations (Schmitt, 2005; Vidal-Gilbert and Tisseau, 2006). The seismic response is then modified during production, and comparing different seismic time-lapses is used to image by-passed areas where a significant oil volume may be still present (Waite et al., 1997; Zhang et al., 2005). The technique is already used is some of the heavy oil fields in Canada and will probably develop in the near future (Fig. 6).

The coupling between fluid-flow and geomechanical modelling is the final step of the reservoir workflow when thermal recovery processes are used (Mainguy and Longuemare, 2002). When the reservoir is made of unconsolidated sands (see section below), the increase of pressure and temperature induces a dilatation of the steam chamber and then cause shear failure within and beyond the growing chamber (Chalaturnyk and Li, 2001; Collins, 2005). Porosity/permeability is then modified and the fluid flow model must be iteratively updated to realistically reproduce the reservoir behaviour during the field depletion.

\subsection{Specific Reservoir Properties of Heavy Oil Fields}

If the in situ oil viscosity is the main limiting factor for the mobility of the heavy oil, adequate petrophysical properties are critical factors to sustain their production. In this respect, the reservoirs must exhibit very high porosity and permeability, compared to the conventional oil plays, to make possible any recovery operation. Typically, and according to current technologies, heavy oil fields need, in order to be producible, to be above $20-30 \%$ porosity (even more in outcropping bitumen belts), and permeability has to be higher than 1 darcy.

As far as clastic reservoirs are concerned, these high porosity and permeability are preferentially found in shallow situation, when porosity was preserved from compaction and late diagenesis. They correspond, for instance, to unconsolidated coarse-grained fluvio-estuarine sediments filling the foreland basins of the Canadian and Orinoco heavy oil belts. Even in this context, only the most porous facies will efficiently contribute to the production. Sands with a finer grainsize or siltstones levels will not contribute significantly to the production and even form permeability barriers. One of the technical challenges that the industry will have to face in the near future will be to develop recovery processes in facies with a lower porosity, opening new opportunities to greatly increase the reserves.

Clastic reservoirs found at shallow depth and which remained at shallow depth (not more than a few hundreds of meters) during the geological history are generally unconsolidated. Specific drilling and completion problems are then 
frequent due to the mechanical behaviour of the unconsolidated sands. On the one hand, sand-influxes may constitute a major problem for producing fluids from these reservoirs, decreasing the production, plugging the bottomhole, and eroding the well and surface equipment. On the other hand, some specific recovery process may benefit from the sand influxes, the sands being produced jointly with the oil. Unconsolidated reservoirs have to face mechanical problems. During cold depletion, a significant compaction may improve the oil recovery during the depletion. Ground surface subsidence is frequently observed in depleted shallow fields, for instance it is the case in heavy oil fields located along or below the Maracaibo Lake where dykes had to be built to avoid risk of lands submersion due to subsidence. The wells are also often deformed if not integrally cased. When steam is injected at shallow depth, the development of the steam chamber is associated to a dilatation of reservoir and of the overburden. Stress regime is modified causing shear failure in the reservoir. The same phenomena may affect also the overburden affecting the cap-rock integrity above the steam chamber. This aspect must be carefully evaluated before increasing pressure in the reservoir during thermal recovery at shallow depth (Schmitt, 2005).
In carbonate reservoirs, lithification usually occurs earlier than for clastic sediments and primary porosity is rapidly lost during early burial. In this respect, carbonates rarely present sufficient poro-perm values to produce from the matrix porosity itself. In the great majority of the cases, carbonates must be fractured to make potential heavy oil reservoirs. But even so, the oil production in such settings which might represent substantial reserves on a regional perspective (Kuwait, Iran, Saudi Arabia) remains challenging and production from fractured carbonate reservoirs has rarely been attempted (i.e. Gela field in Italia).

\subsection{The Reservoir Architecture of Fluvial Channels}

Fluvial and fluvio-deltaic reservoirs contain most of the heavy oil in place in the two main provinces of Canada and Venezuela, but also in California, Indonesia, etc. We will describe in the following sections the type of heterogeneity which can be found in the fluvio-estuarine reservoirs of the Canadian heavy oil belt. The model can also be easily applied to the Orinoco heavy oil belt which reservoirs present a very similar organization and architecture than the ones in

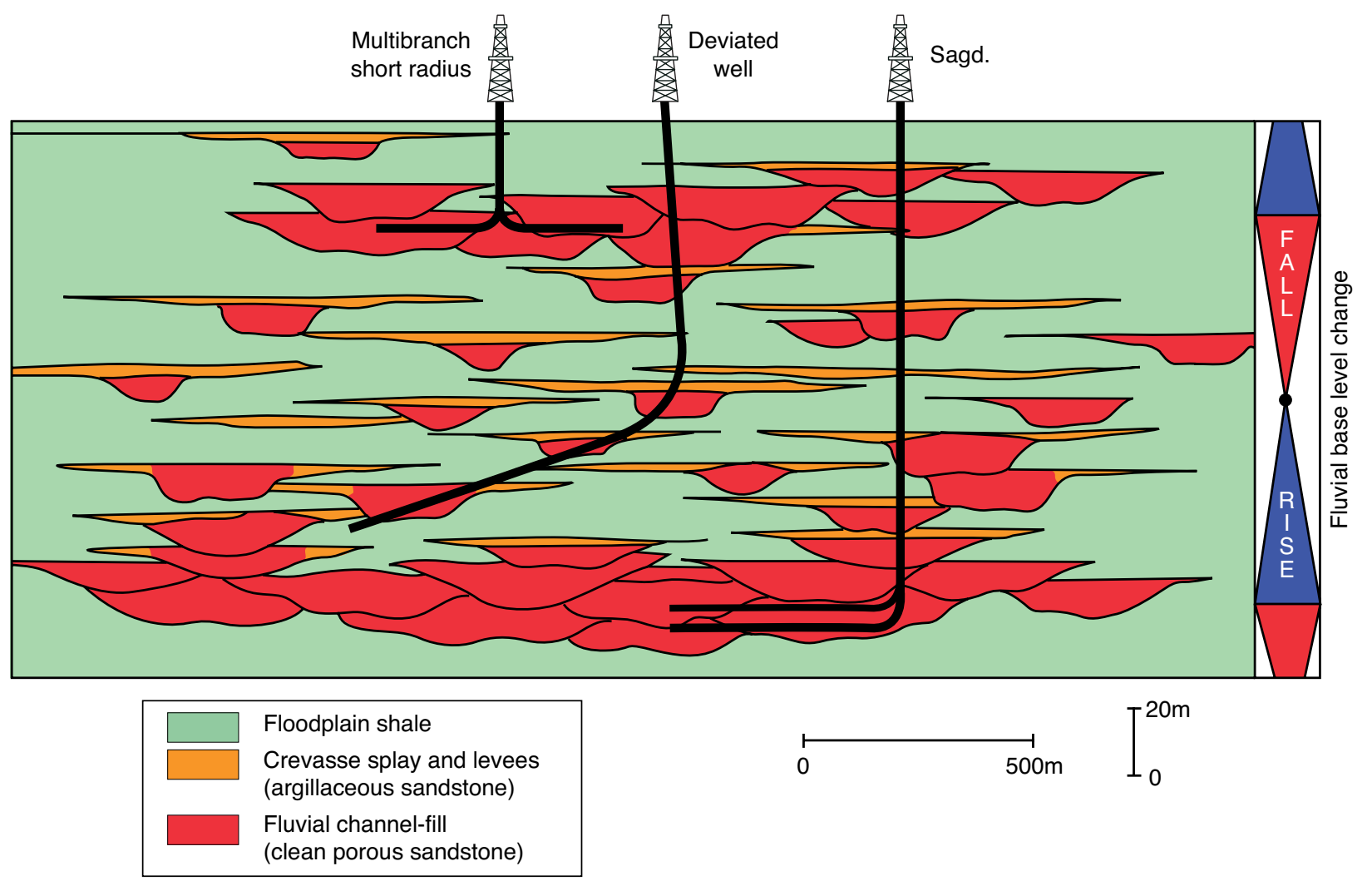

Figure 7

Typical organization of fluvial reservoirs and possible well pattern for producing heavy oil depending on the channel connectivity. At the base of the fluvial cycle, the channels are amalgamated in channel belts forming a laterally continuous reservoir unit. As the base-level rose, the floodplain shale were better preserved between the channels. 

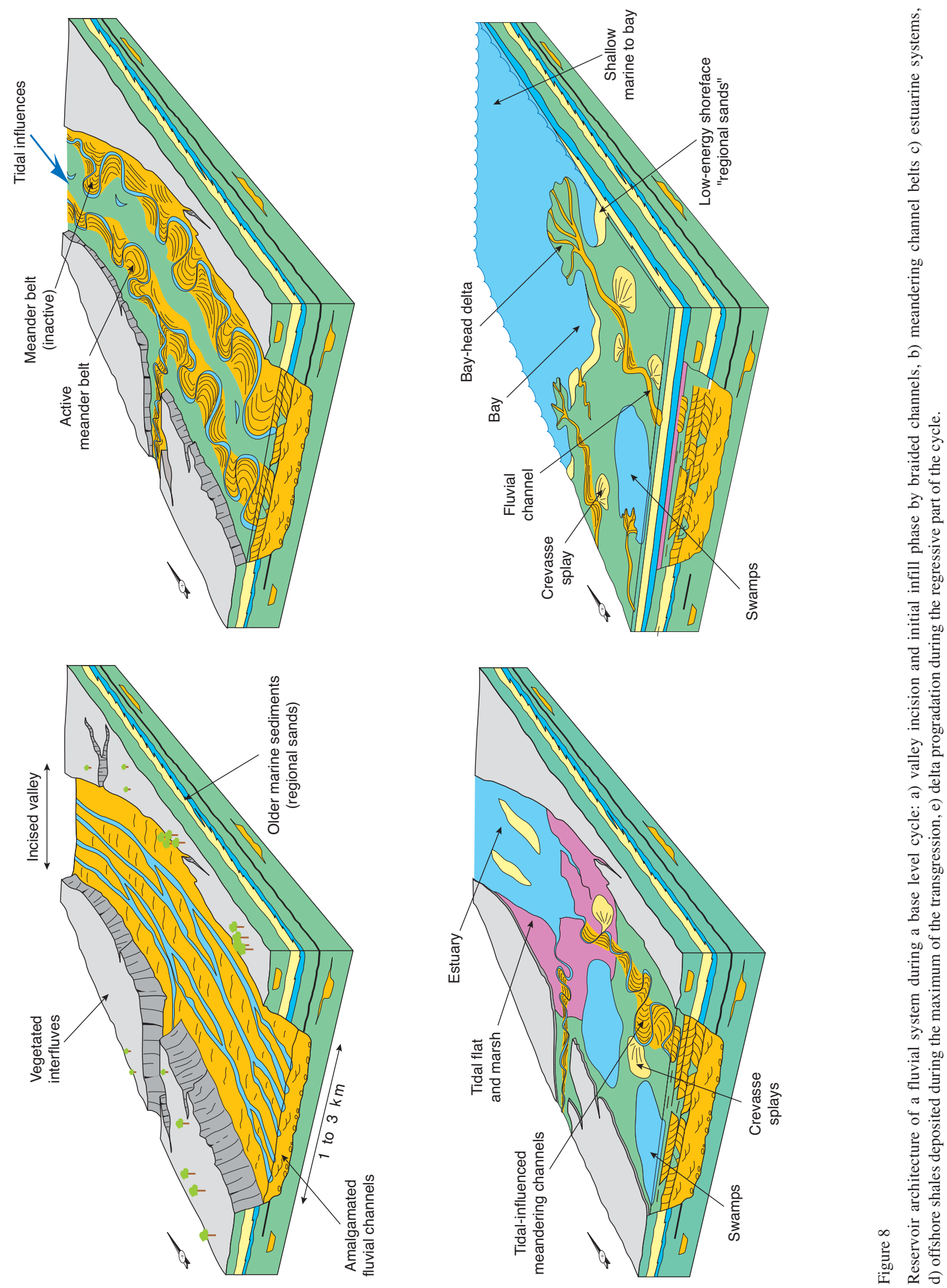
Canada (Kopper et al., 2001). Similarly, heavy oil fluvial reservoirs can also be found in Albania, California, China, Indonesia, etc.

As said above, fluvial reservoirs are sand-rich, but very heterogeneous at every scale. The reservoirs correspond to ancient fluvial channels filled by a sandy material with a high Net/Gross, and the channel laterally interfinger with shaleprone floodplain deposits. The channel dimensions is the first uncertainty for the reservoir development Laterally to the channels, overbank deposits, (crevasse splays, levees, etc.), made of finer-grained material, do not contribute to the production of heavy oil because of their low porosity and permeability. Siltstones beds also constitute permeability barrier to the heavy oil production in the channel-fill themselves (Williams et al., 2001).

The architecture of fluvial reservoirs is mostly controlled by the rate of incision and amalgamation of the channels. Fluvial systems are typically organized $\mathrm{n}$ cycles corresponding to the variation of the base level through time, which results from the complex interaction of subsidence and climate controlling itself the water influx and the sediment supply in the river systems (Posamentier and Vail PR, 1988; Shanley and McCabe, 1994).

The variation of the base level during geological times induced changes in the rate of amalgamation of the channels. At the base of a cycle, when base level starts to rise, channels were amalgamated to form sand-rich channel belt. The width of the channel belt varies from a few kilometres to hundreds of kilometres. They form sand-sheets with a high sand-shale ratio, but with also a high degree of heterogeneity, each channel cross-cutting the underlying ones. The sand-sheets will be preferentially developed by horizontal wells to get the maximum pay in the wells (Fig. 7). In these sand-sheets, a finescale heterogeneity may locally affect the well productivity and may also strongly impact the development of a steam chamber.

The base-level continuing to rise, the floodplain shales will be preserved between the channels. As a result, vertical connectivity between channels also decreases. Individual channels will be produced by putting wells parallel to the channel orientation, or by drilling deviated wells to statistically increase the chance to cross-cut several channels in the same well.

\subsection{The Reservoir Architecture of Incised Valleys}

Many reservoirs in which heavy oil can be found in Canada or Venezuela corresponds to ancient fluvial valley-fills. It is then important to understand the sedimentology of such reservoirs to be able to predict the heterogeneity distribution.

The valleys were formed during periods of base level fall, rivers incising the sediments below with a sharp basal erosional surface (Fig. 8). As the base level started to rise, high- energy braided channels filled the basal part of the valley with coarse-grained material. The base level continuing to rise, the fluvial systems changed to meandering channels overlying the braided channels (Eschard et al., 1991). Then the sea progressively invaded the valley and the effect of the tidal action can be seen in the upper of the valley with the deposition of heterolithic sandstones and mudstones in estuarine channels and tidal flats. Marine sediments can even be deposited if the sea-level rise continued. When the relative sea-level rise slowed, an overall progradation of a delta plain sealed the valley, facies being more and more proximal upward before the occurrence of a new fluvial incision during the next base-level fall. Such cycles are commonly found in the Cretaceous succession of Alberta and Saskatchewan (Canada), or in the Miocene succession of the Orinoco (Venezuela). Each of the unit forming the reservoir is marked by a specific organization of the facies and then, of the heterogeneity distribution. The basal part of it is sand-rich and relatively homogeneous, while the meandering then the tidal channels are less continuous and highly heterogeneous at a fine-scale, which makes the production of heavy oil much more challenging in these upper units.

\subsection{Heavy Oil in Fluvial Reservoirs: the Example of the Cretaceous Mannville Group, Canada}

\subsubsection{Regional Setting of the Mannville Group}

We describe in this section some typical reservoirs of the Lower Cretaceous Mannville Group in Western Canada which corresponds to one of the most prolific heavy oil province of the world. As previously said, the model of heterogeneity distribution of the Canadian heavy oil reservoirs can also be applied in many other similar geological contexts, specially in the Orinoco heavy oil belt (Venezuela). The deposition of Mannville Group was contemporaneous of the formation of a foreland basin during Middle Cretaceous times (Cant, 1996). The succession is $700 \mathrm{~m}$ in the foothill area westwards while it progressively thins out to few tens of meters when approaching the outcrops belt eastwards (forebulge area). The heavy oil province in Canada is located when approaching the forebulge at shallow depth. As said in the previous sections, the oil viscosity increases when approaching the outcrops, forming the bitumen belt of Alberta and Saskatchewan (Athabasca, Cold lake sands etc.). Even if the reservoir unit is continuous between the sursurface and the outcrops, regional facies changes are recorded which affect the reservoir architecture. Furthermore, the burial depth may have a significant impact on the heterogeneity behaviour during production (Hein et al., 2000; EUB Report, 2003).

Fluvio-deltaic sediments of the Mannville Group onlap a major unconformity eroding underlying Paleozoic carbonates in Saskatchewan. The Lower part of the Mannville group 

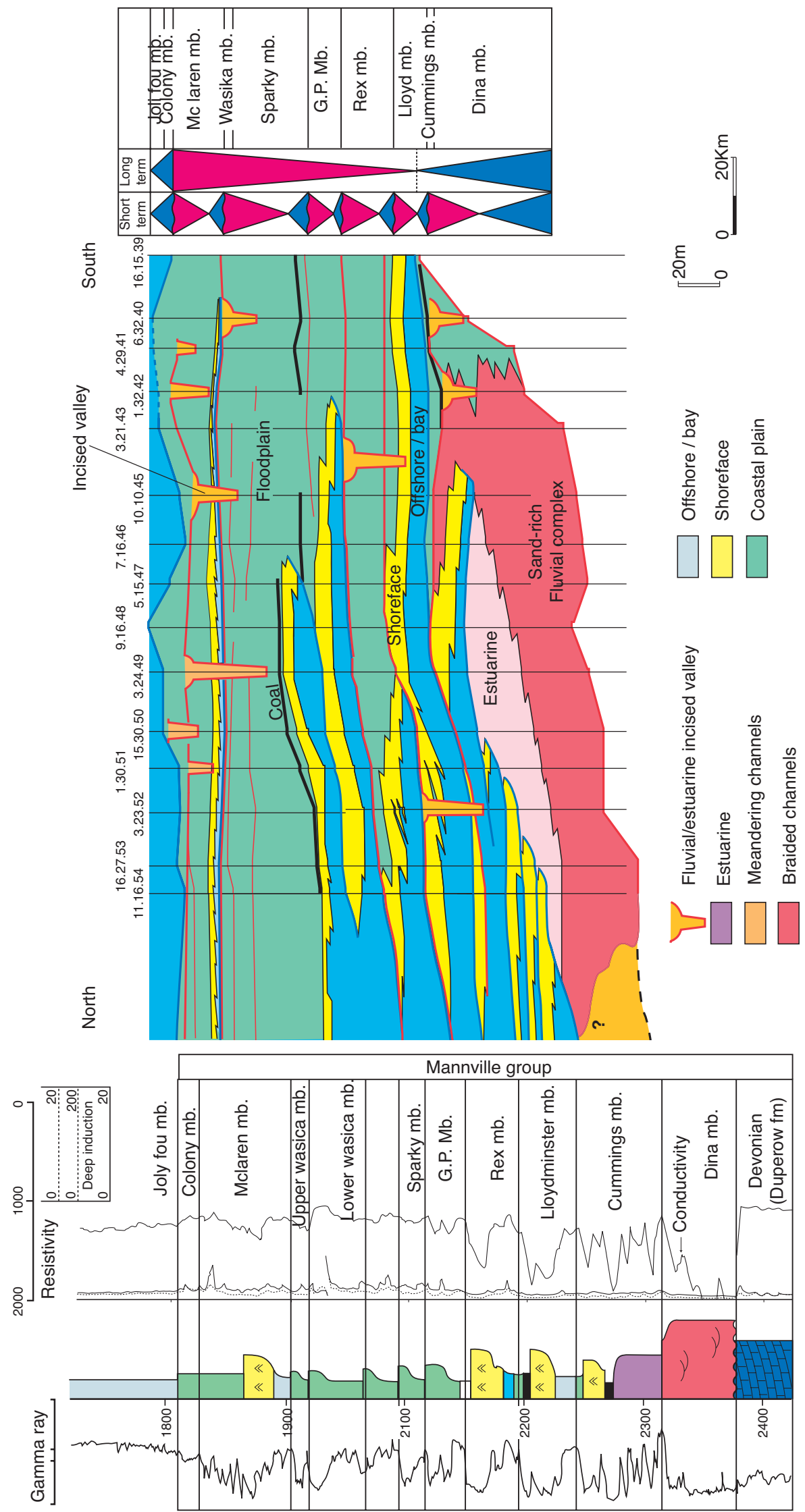

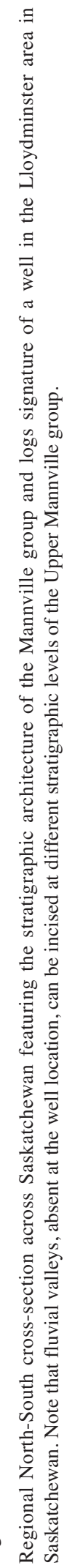




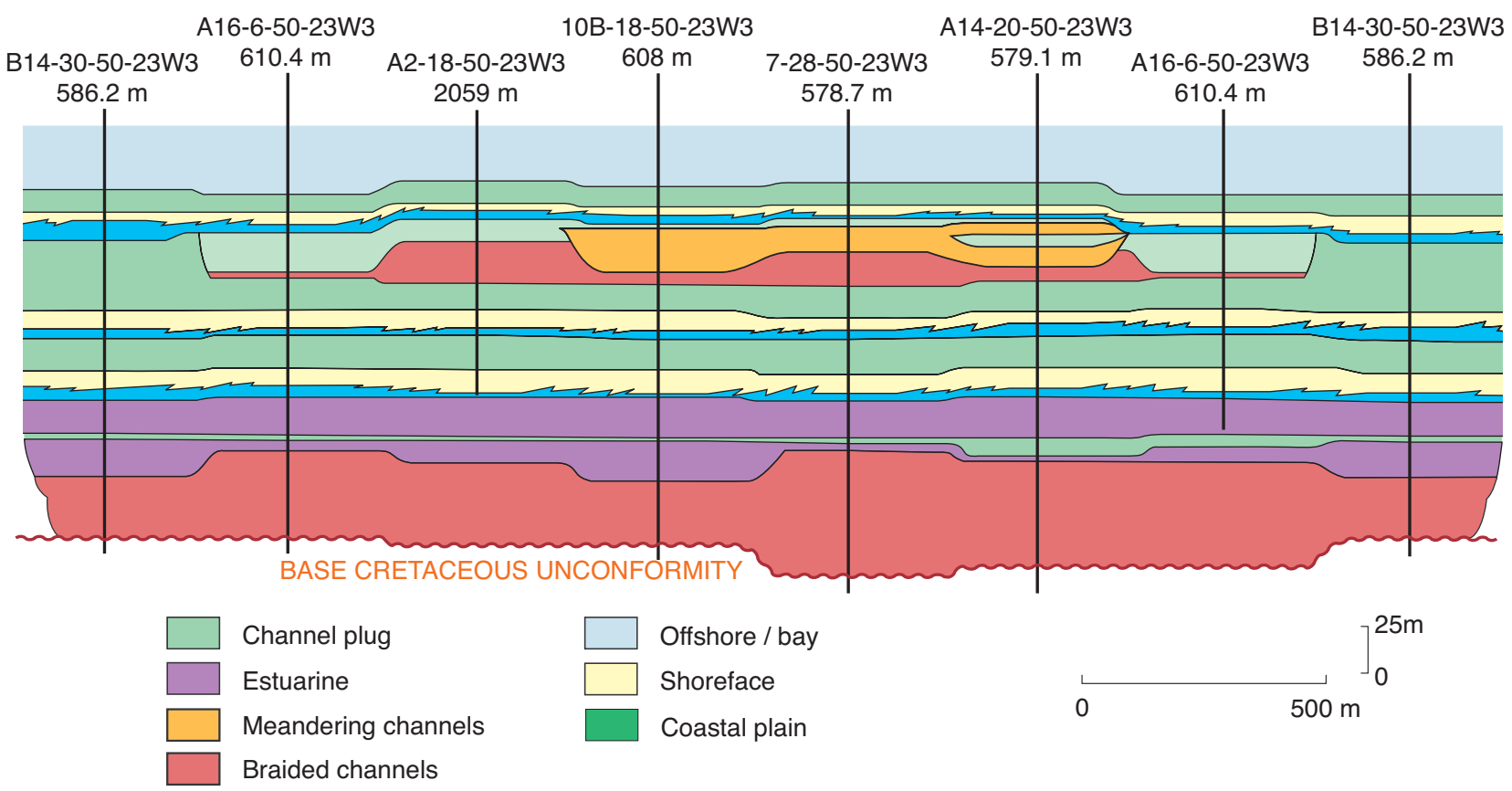

Figure 10

Cross section across a producing field in Saskatchewan showing the reservoir geometry in the Mannville Group. Note the sand-rich continuous fluvial basal reservoir layer (red) overlaid by a layer of heterogeneous estuarine facies (violet). In the upper part of the section, a narrow incised valley also shows mudstone plugs. Seismic time slices of this upper valley-fill can be seen in Figure 14, while an illustration of the estuarine channel architecture (violet layer) can be seen in a similar context in a seismic horizon slice in Figure 13.

mostly consisted of fluvial and estuarine sediments onlapping the unconformity (Fig. 9). A network of large incised fluvial valleys first developed, the location of which was partly controlled by the differential erosion of the underlying Paleozoic strata and by local tectonic movements possibly due to salt dissolution in the Paleozoic (Hayes et al., 1994; Leckie et al., 1997). Interfluves remained subaerially exposed during the infill of the valleys at the base of the Mannville Group, and were latter onlapped by younger sediments. The river systems were flowing northwards towards the boreal ocean, the fluvial systems distally passing to deltaic sediments (Nardin et al., 2007). During Albian times, a relative sea-level rise induced an overall backstep of the fluvial systems, depositing first fluvial sediments (Dina Member) then estuarine sediments (Cummings Member) in the valleys. Above, marine sediments overwhelmed the valley themselves and blanketed the whole area forming the seal of the incised valley systems (Lloydminster Member, Fig. 9).

The upper part of the Mannville Group consisted of shallow marine and brackish sediments alternating with fluvial sediments. At least five transgressive-regressive cycles can be regionally correlated. Each of the cycles began with a relative sea-level drop of variable amplitude inducing a network of incised valleys (Karnoven and Pemberton, 1997). The correlative marine lowstand wedges can be found northwards (Hayes et al., 1994; Mc Phee and Pemberton, 1994; Cant DJ, 1996). The valley width is often less than a kilometer, for a depth which can reach $30 \mathrm{~m}$ (100 ft) or more. Valleys were then filled during the subsequent sea-level rises: the valleys were first filled with fluvial sediments then by tidal deposits, forming the main reservoir. A layer of marine or brackish shales of regional extension was deposited during the maximum of the transgression forming the seal of the reservoir. Then, shoreface, bay-head deltas and mouthbar overlaid by floodplain shales and coals prograded during the regressive part of the cycle, forming "regional sands" a few meters thick, before a new fluvial incision. A North-South cross-section summarizing the stratigraphic architecture of the Mannville Group across Saskatchewan is shown in Figure 9, together with typical well section of the Mannville Group in East-central Saskatchewan. Figure 10 also illustrates the typical reservoir architecture of a producing field in 


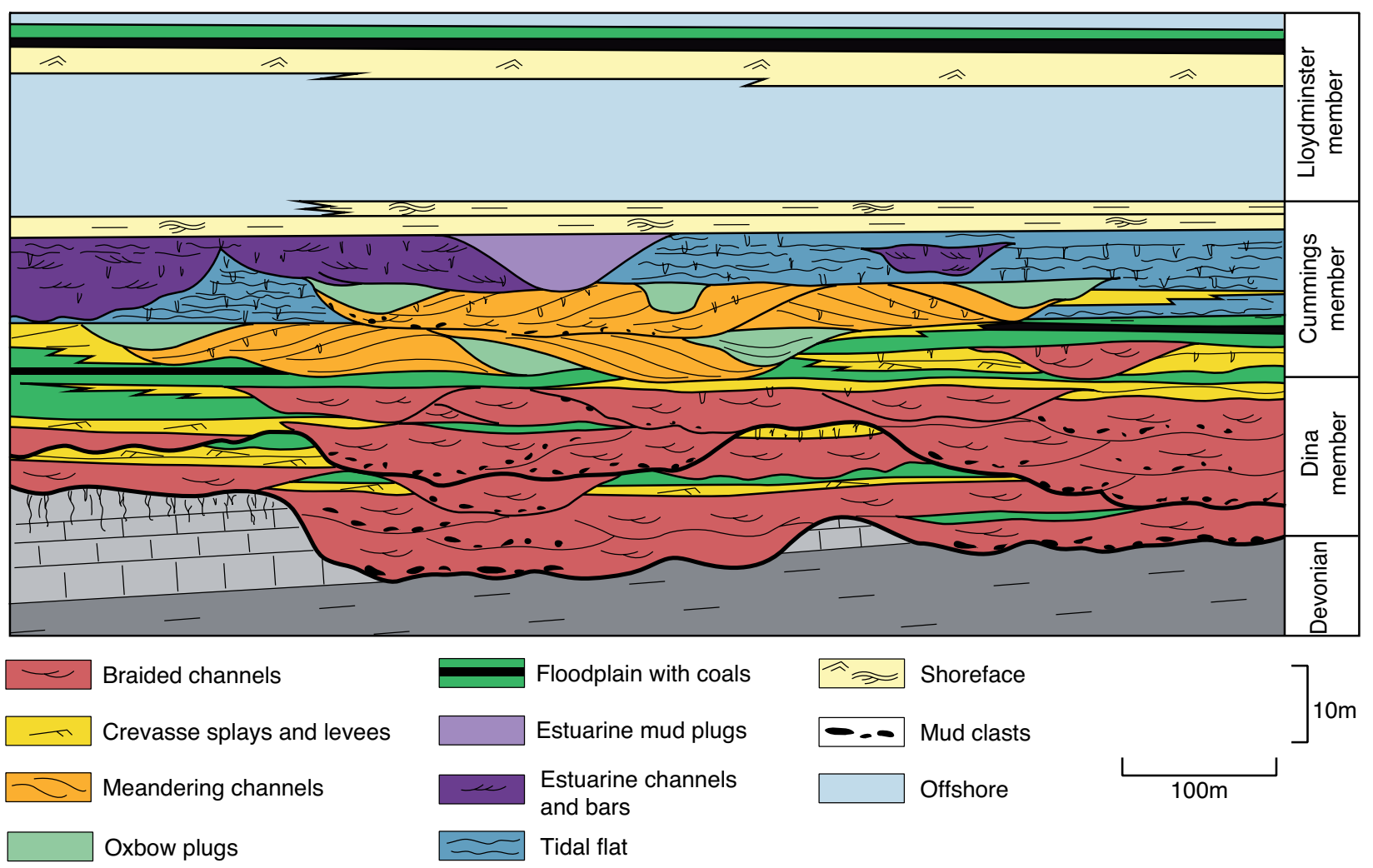

Figure 11

Conceptual model of the heterogeneity distribution in the Lower Mannville Group. The basal braided channels are overlaid by meandering channels which in turn pass to tidal flats and estuarine channels. The reservoir heterogeneity consists of locally preserved floodplain mudstones and siltstones, mud-clast layers, abandoned channel plugs and mud drapes developed on the point bar of the meandeering channels and in the tidal facies.

Saskatchewan, with two stacked reservoir units. The lower one makes a basal continuous heterogeneous sand-sheet and above, a narrow incised valley is encased in non-reservoir floodplain shales.

\subsubsection{Reservoir Heterogeneity in the Fluvial Reservoirs of Saskatchewan}

A theoretical model of the distribution of the heterogeneity in the reservoirs of the Lower Mannville group is shown in Figure 11. In East Saskatchewan, the basal sands, the main producing reservoir (Dina Member), consists of very-coarse grained unconsolidated sands deposited in amalgamated braided channels (Fig. 12). Several cycles of incisions may have occurred during the infill of the valley system, adding a complexity in the reservoir architecture of this unit. The braided channel-fill displays two main types of heterogeneity: (1) mud-clasts layers draping each of the channel basal erosion surfaces. These mud-clasts layers are discontinuous and in general, do not make any significant barrier to the flow or injected fluids, but contribute to reduce the vertical permeability of the layer. However, the mud-clast layer may have a different behaviour during steam injection depending on the field, and in some cases, significantly hinder the steam chamber development (Ito et al., 2000); (2) siltstone or mudstone layers preserved on top of the channel sequence, which may reach a few hundreds of meters of lateral extension for a few meters or less of thickness. Such an heterogeneity significantly reduces the vertical permeability in the basal sand sheet and the sweeping efficiency of water or steam injection. This, for instance, can dramatically affect the productivity of well pairs in the SAGD process, even if the thinner permeability barriers will be broken with high injection pressures and thermal effects.

Above the basal fluvial sand-sheet, meandering channels and estuarine facies form a very heterogeneous layer (Cummings Formation) at every scale. Channels laterally interfinger with floodplain shales or tidal flats. Meandering channels also show curved and inclined lateral accretion sur 


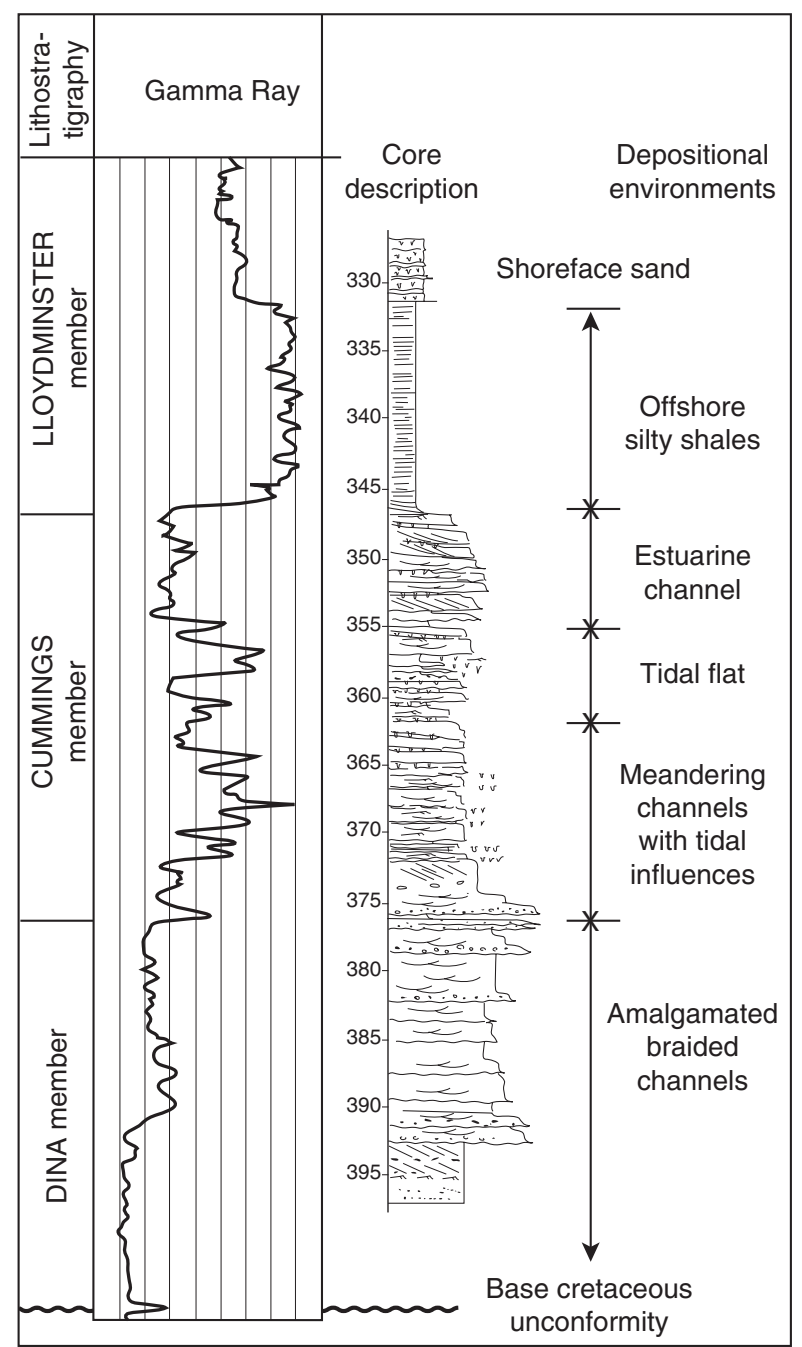

Figure 12

Log and core description of an heavy oil well (Lower Mannville Group, Saskatchewan). The valley-fill typically displays a fining upward evolution. The coarse-grained basal sands were deposited in braided channels (Dina Member) and were overlaid by bioturbated point bars of meandering channels, then by tidal deposits (Cummings Member) before the transgression of offshore shales forming the reservoir seal (Lloydminster Member).

faces themselves draped with thin mud-layers which significantly reduce porosity and permeability of these units. Such arcuate feature, corresponding to points bars, can be seen in 3D high-resolution seismic data (Sarzalejo and Hart, 2006) (Fig. 13). The facies is named Inclined Heterolithic Surface (I.H.S.) by Canadian geologists (Strobl et al., 1997), and producing such heterogeneous facies still remains a technical challenge. Mud-plugs, corresponding to the final abandonment of a meander bend, are also present laterally to the point bars and form a significant heterogeneity in a reservoir layer.
On top of the valley-fill, estuarine channels interfingering with tidal flat form a very heterogeneous layer, high porosity channel-fill being embedded in non-reservoir facies. As a result, the porosity and permeability of these layers abruptly drop and the layer is generally not considered as an economic reservoir.

Incised valley in the Upper part of the Mannville Group are much narrower than the basal regional sands. A facies map interpreted from seismic data of an incised fluvial channel (Colony Member) is shown in Figure 14. The channel has maximum thickness of $33 \mathrm{~m} \mathrm{(100} \mathrm{ft)} \mathrm{and} \mathrm{is} \mathrm{less} \mathrm{than} \mathrm{a} \mathrm{kilo-}$ metre wide $(0.6$ miles $)$. The valley fill displays a fining upward sequence. Massive blocky basal sands are overlain by heterogeneous facies. Mean porosity in the basal sand is $33 \%$ and mean permeability is around 4 Darcies.

The sedimentological heterogeneity is not the only one which can cause problem in heavy oil reservoir production. Variation of fluid saturation and viscosity also have a strong impact on the recovery, specially with thermal processes. This is particularly the case when a layer presents higher water saturation within the reservoir. A leakage of the steam may then occur through this "thief zone", reducing the growth of the steam chamber. Similarly, steam leakage may also occur through the oil-water transition zone, and the phenomena is particularly problematic in reservoirs with superposed oil-water contacts.

\section{CONCLUSIONS}

The vast majority of heavy oil accumulations are the result of biological activity altering former conventional oils. The main factors controlling the process are the physiological conditions required by the in situ bacterial communities including adequate temperature scenario of the reservoir and availability of inorganic nutrients. On a case to case basis the understanding and the prediction of the occurrence, and extend, of biodegradation relies on a good insight on the geological circumstances embodying the field accumulation formation, including static and dynamic information such as architecture and burial history of the reservoir, timing and rate of oil charging, hydrodynamism, occurrence and timing of meteoric water influx etc. Current reservoir characterisation and modelling workflows, basin modelling packages provide already useful tools for helping in the understanding and prediction of biodegradation in oil fields and prospects. Dedicated improvements of these approaches, such as local grid refining and adapted time step resolution (basin simulators) and modelling of the oil invasion during charging, instead of oil displacement of producing fields (reservoir simulators) would probably increase considerably our ability to address the biodegradation aspect for the sake of exploration. 


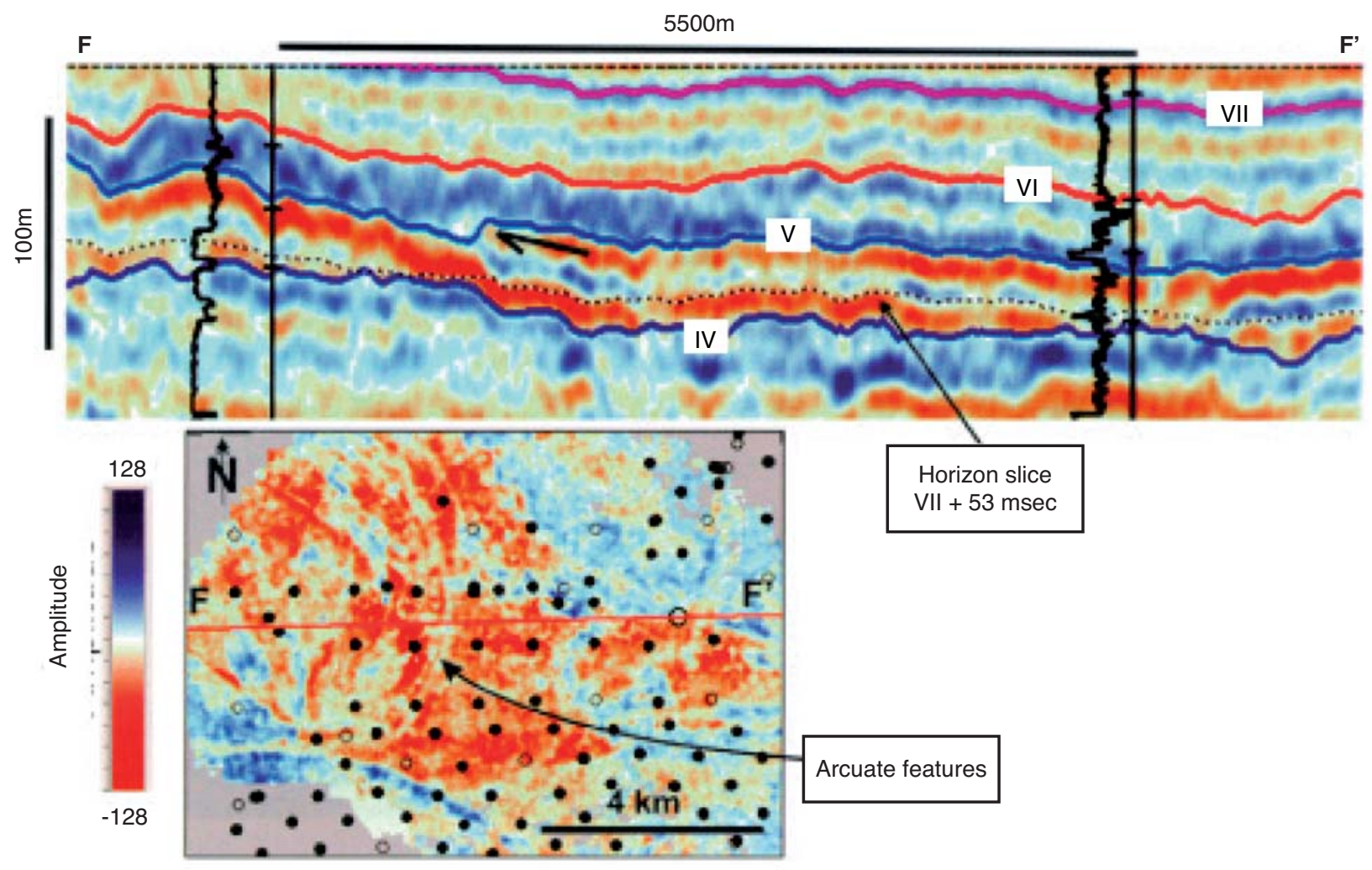

Figure 13

Seismic profile and stratal slice in the Upper Mannville Group of S.E. Saskatchewan (from Sarzalejo and Hart, 2006). The arcuate features seen on the stratal slice corresponds to the point bar of a meandering channel.

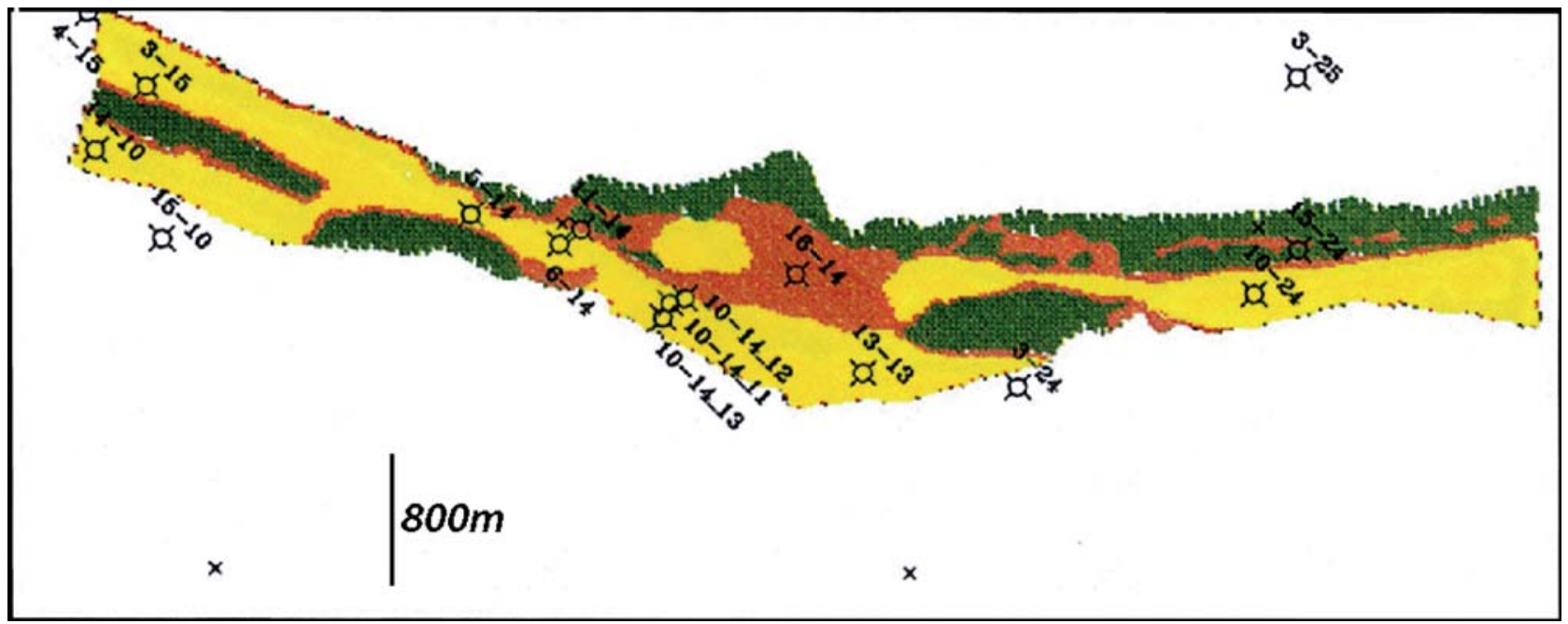

Figure 14

Seismic facies in an incised valley of the Upper Mannville Group, Saskatchewan, Canada (yellow: clean porous sands, orange: argillaceous sands; green: shale). The valley is $30 \mathrm{~m}$ thick and corresponds to the upper reservoir in the cross-section in Figure 10. 
As far as production is concerned, the effect of the heterogeneities, including reservoir heterogeneities and spatial variations of fluids properties, on the sweeping efficiency is critical in heavy oil fields. The high viscosity of the oil hinders its displacement in the porous media around the well. To improve production, a close well spacing is needed and horizontal, complex multidrains are often preferred to increase the well productivity together with EOR techniques.

The effect of the reservoir heterogeneity on the sweep efficiency is critical when a fluid is injected to displace or heat the heavy oil. The reservoir facies of heavy oil fields corresponds to unconsolidated sands with very high ranges of porosity (above 20\%) and permeability (above 1 Darcy). As a result, even facies with a medium range of porosity will act as barrier to the fluid flow. Producing from layers with lower ranges of porosity/permeability is one of the next technical challenge to increase the reserves of a given field. In the case of the thermal processes, reservoir heterogeneity surely affects the steam chamber development and then influence the productivity of well and well pairs (Ehlig-Economides et $a l ., 2001)$. For all the reasons cited above, a well-managed field development in heavy oil reservoirs should integrate a more detailed reservoir description than usually required in conventional oil plays (Williams et al., 2001) and this description should be integrated in fluid-flow models.

We are now facing several technical challenges to adapt our reservoir workflow to the specificity of heavy oil reservoirs:

- the real-time updating of the well trajectory and of the reservoir models when tens of shallow wells are drilled in short periods of time (for example, Orinoco heavy oil prospects in Venezuela (Uzcategui, 2001);

- the use of 4D time lapse and cross-well seismic to image the reservoir and monitor the evolution trough time of the fluid saturation or of a steam chamber, and then identify potential by-passed areas (Kopper R et al., 2001);

- the coupling between fluid flow and geomechanical models, combined to a quantified interpretation of 4D seismic data, to predict the reservoir behaviour when thermal recovery processes are used. This new workflow will be the key to efficiently manage heavy oil production and increase the recovery in the near future.

\section{REFERENCES}

Aitken C.M., Jones D.M., Larter S.R. (2004) Anaerobic hydrocarbon biodegradation in deep subsurface oil reservoirs, Nature 431, 291-294.

Bashari A. (1988) Occurrence of heavy crude oil in the Persian Gulf, 4th Unitar/UNDPP International conference on heavy crude and tar sands, Edmonton, Alberta, Canada, 7-12 August 1988, Proceedings paper No. 44.

Bennett P.C., Hiebert F.K., Rogers J.R. (2000) Microbial control of mineral-groundwater equilibria: macroscale to microsacle, Hydrogeol. J. 8, 47-62.
Blanc Ph., Connan J. (1993) Crude oils in reservoirs: the factors influencing their composition, in Applied Petroleum Geochemistry, Bordenave M.L. (Ed.), Editions Technip, Paris, pp. 149-174.

Cant D.J. (1996) Sedimentological and sequence stratigraphic organization of a foreland clastic wedge, Mannville Group, Western Canada basin, J. Sediment. Res. 66, 1137-1147.

Capeleiro Pinto A.C., Gudes S.S., Bruhn C.H.L., Gomes J.A., de Sa A.N., Fagundes Netto J.R. (2001) Marlin Complex Development: a reservoir engineering point of view, SPE 69438.

Chalaturnyk R.J., Li P. (2001) When it is important to consider geomechanics in SAGD operations? Proceedings of petroleum Society of CIM Can. Int. Pet. Conf., Calgary, Alberta, 12-14 June 2001, Paper 2001-46.

Collins P.M. (2005) Geomechanical Effects on the SAGD Process. SPE/PS-CIM/CHOA 97905, PS2005-405, 2005 SPE International Thermal Operation and Heavy oil Symposium, Calgary, Alberta, 1-3 November 2005.

Curtis C., Kopper R., Decoster E., Guzman-Garcia A., Huggins C., Knauer L., Minner M., Kupsch N., Linares L.M., Rough H., Waite M. (2002) Heavy Oil Reservoirs, Oilfield Rev., 30-51.

Demaison G.T. (1977) Tar sands and super giant oil fields, Am. Assoc. Pet Geol. Bull. 61, 1950-1961.

Demaison G.T., Huizinga G.J. (1994) Genetic classification of petroleum systems using three factors: charge, migration and entrapment, in The petroleum system, from source to trap, Magoon L.B., Dow W.G. (Eds.), AAPG Memoir 60, pp. 73-92.

Dequirez P.Y., Fournier F., Blanchet C., Feuchtwanger T., Torriero D. (1995) Integrated stratigraphic and lithologic interpretation of the East-Senlac heavy oil pool, 65th Annual International Meeting of the Society of Exploration Geophysicists, Houston, 8-13 Oct. 1995, Expanded Abstracts.

Deroo G., Powell T.G., Tissot B., Mc Crossan R.G. (1977) The origin and migration of petroleum in the Western Canadian sedimentary basin, Alberta, Bull. Geol. Surv. Canada.

Ehlig-Economides C.A., Fernandez B., Economides M.J. (2001) Multibranch injector/producer wells in thick heavy oil-crude reservoirs, SPE Reservoir Evaluation J. 4, 3, 195-200.

Eschard R., Ravenne C., Houel P., Knox R. (1991) Three-dimensional reservoir architecture of a valley-fill sequence and a deltaic aggradational sequence: influences of minor relative sea-level variations (Scalby formation, England), in The three-dimensional facies architecture of terrigenous clastic sediments and its implications for hydrocarbon discovery and recovery, Miall A.D., Tyler N. (Eds.), SEPM, Concepts in sedimentology and paleontology, Vol. 3, pp. 133-147.

EUB Report (2003) Athabasca Wabiskaw-McMurray regional geological study, Report 2003-A, Alberta Energy and Utility board, Calgary, Alberta.

Evans C.R., Rogers M.A., Bailey N.J.L. (1971) Evolution and alteration of petroleum in Western Canada, Chem. Geol. 8, 147170 .

Hayes B.J.R., Christopher J.E., Rosenthal L., Los G., McKercher B., Minken D., Tremblay Y.M., Fennell J. (1994) Cretaceous Mannville Group of the Western Canada Sedimentary Basin, in Geological Atlas of the Western Canada Sedimentary Basin, Mossop G.D., Shetson I. (Eds.), Canadian Society of Petroleum Geologists and Alberta Research Council, Calgary, Alberta.

Head I.M., Jones D.M., Larter S.R. (2003) Biological activity in the deep subsurface and the origin of heavy oil, Nature $\mathbf{4 2 6}$, 344-352. 
Hein F.J., Cotterill D.K., Berhane H. (2000) An Atlas of the McMurray Formation Athabasca Oil Sands Deposits, northeastern Alberta: Surface and Subsurface, EUB Report 2000-07, Alberta Energy and Utility Board, Alberta Geological Survey, Edmonton, Alberta.

Horstad I., Larter S.R., Mills N. (1992) A quantitative model of biological petroleum degradation within the Brent Group reservoir in the Gullfaks field, Norwegian North Sea, Org. Geochem. 19, 107-117.

Isaacs C.M., Rullkötter J. (2000) The Monterey formation, from rocks to molecules, Columbia University Press, New York, 553 p.

Ito Y., Ichikawa M., Hirata T. (2000) The growth of the steam chamber during the early period of the UTF Phase B and Hanginstone phase I projects, paper 2000-5, Petroleum Society's Canadian International Petroleum Conference 2000, Calgary, Alberta, 4-8 June 2000

Jayasekera A.J., Goodyear S.G. (2000) The Development of heavy oil fields in the United Kingdom Continental shelf: past, present and future, SPE Reservoir Eval. Eng. 3, 371-379.

Jeans P.J.F., van Meerbeke G.L.E. (2006) Geological evolution and hydrocarbon habitat of the Majunga basin and Karroo corridor, Madagascar. http://www.pj-exploration.com/madagascar.htm

Jobson A.M., Cook F.D., Westlake D.W.S. (1979) Interaction of aerobic and anaerobic bacteria in petroleum biodegradation, Chem. Geol. 24, 355-365.

Karnoven R.L., Pemberton S.G. (1997) The Upper Mannville Group, Western Canada: an example of multiple incised valley fill deposits, in Petroleum Geology of the Cretaceous Mannville Group, Western Canada, Pemberton S.G., James D.P. (Eds.), Canadian Society of Petroleum Geologists, Memoir 18, pp. 124-139.

Kopper R., Kupecz J., Curtis C., Cole T., Dorn-Lopez D., Copley J., Munoz A., Caicedo V. (2001) Reservoir Characterization of the Orinoco Heavy oil belt: Miocene Oficina Formation, Zuata field, Eastern Venezuela, SPE 69697.

Kowalewski I., Carpentier B., Magnier C., Huc A.Y. (in press) Use of heavy metals content for quantitative estimation of biodegradation, in special publication $J P G E$.

Larter S., Gates A., Adams J., Bennet B., Huang H., Kosalan T., Fustic M. (2006) Reservoir fluid characterization of tar sand and heavy oil reservoirs - Impact of fluid heterogeneity on production characteristics, AAPG 2006 Annual Convention, Houston, USA, Abstracts volume, p. 60.

Leckie D.A., Vansbeselaere N.A., James D.P. (1997) Regional sedimentology, sequence stratigraphy and petroleum geology of the Mannville Group: southwestern Saskatchewan, in Petroleum Geology of the Cretaceous Mannville Group, Western Canada Pemberton S.G., James D.P. (Eds.), Canadian Society of Petroleum Geologists, Memoir 18, pp. 211-262.

Magnier C., Moretti I., Lopez J.O., Gaumet F., Letouzey J. (2004) Geochemical characterization of source rocks, crude oils and gases of northwest Cuba, Mar. Petrol. Geol. 21, 195-214.

Magot M., Ollivier B., Patel B.K.C. (2000) Microbiology of petroleum reservoirs, Antonie van Leeuwenhoek Int. J. Gen. Mol. Microbiol. 77, 103-116.

Mainguy M., Longuemare P. (2002) Coupling Fluid Flow and Rock Mechanics: Formulation of the Partial Coupling between Reservoir and Geomechanical Simulators, Oil Gas Sci. Technol. - Rev. IFP 57, 4, 355-367.

Mason P.C., Burwood R., Mycke B. (1995) The reservoir geochemistry and petroleum charging histories of Paleogenereservoired fields in the Outer Witch Ground Graben, Cubitt
J.M., England W.A. (Eds.), The Geochemistry of Reservoirs, Geological Society Special Publication 86, 281-301.

Mc Phee D., Pemberton S.G. (1994) Sequence stratigraphy of the Lower Cretaceous Mannville Group of East Central Alberta, Canadian Society of Petroleum Geologists, Exploration Update 1994, Program with Abstracts, pp. 27-28.

Nardin T., Carter J., Falls B., Irish J., Stancliffe S., Varban B., Wilson N., Zabcic L., Pratt L., (2007) Sequence stratigraphic and depositional facies framework of the Lower Cretaceous McMurray Formation, Kearl Oil Sands project, Alberta, Extended Abstract, 2007 C3 Geoconvention, May 16th-17th, Calgary, Alberta.

Niu J., Hu J. (1999) Formation and distribution of heavy oil and tar sands in China, Mar. Petrol. Geol. 16, 85-89.

Peters K.E., Walters C.C., Moldowan M.M. (2005) The Biomarker guide, 2nd ed., 2 volumes, Cambridge University Press.

Posamentier H.W., Vail P.R. (1988) Eustatic controls on clastic deposition II - Sequence and System tracts models, in Sea-level changes: an integrated approach, Wilgus C.K. et al. (Eds.), pp. 125-154.

Roure F., Naszaj S., Mushka K., Fili I., Cadet J.P., Bonneau M. (2004) Kinematics and petroleum systems - An appraisal of the Outer Albanides, McKlay K.R. (Ed.), Thrust Tectonics and Hydrocarbon systems, AAPG Memoir 82, pp. 474-493.

Sarzalejo S., Hart B.S. (2006) Stratigraphy and lithologic heterogeneity in the Mannville Group (southeast Saskatchewan) defined by integrating 3-D seismic and log data, Bull. Can. Petrol. Geol. $\mathbf{5 4}, 138-151$.

Schmitt D.R. (2005) Rock Physics and Time-lapse Monitoring of Heavy-Oil Reservoirs. SPE/PS-CIM/CHOA 98075, PS2005-435, presented at the 2005 SPE International Thermal Operation and Heavy oil Symposium, Calgary, Alberta, 1-3 November 2005.

Shanley K.W., McCabe P.J. (1994) Perspectives on sequence stratigraphy of continental strata, AAPG Bull. 78, 544-568.

Strobl R.S., Muwais W.K., Wightman D.M., Cotterill D.K., Yuan L. (1997) Geological modelling of the McMurray Formation reservoirs based on outcrop and subsurface analogues, in Petroleum Geology of the Cretaceous Mannville Group, Western Canada, Pemberton S.G., James D.P. (Eds.), Canadian Society of Petroleum Geologists, Memoir 18, 292-311.

Svanes T., Martinius A.W., Hegre J., Maret J.P., Mjøs R., Molina J.C.U. (2004) Integration of subsurface applications to develop a dynamic stochastic modelling workflow, AAPG Bull. 88, 1369-1390.

Tissot B.P., Welte D.H. (1984) Petroleum formation and occurrence, Springer-Verlag, $699 \mathrm{p}$.

Uzcategui E. (2001) Reservoir characterization and exploitation scheme in the Orinoco belt, SPE 69698 presented at the 2001 SPE International Thermal Operations and Heavy Oil Symposium, Porlamar, Margarita Island, Venezuela, 12-14/03/01.

Vidal-Gilbert S., Tisseau E. (2006) Sensitivity Analysis of Geomechanical Behaviour on Time-Lapse Seismic Velocity Modeling. SPE 1001142, presented at the SPE/EAGE Annual Conference and Exhibition, Vienna, Austria, 12-15 June 2006.

Waite M.W., Sigit R., Rusdibiyo A.V., Susanto T., Primaldi H., Satriana D. (1997) Application of seismic monitoring to manage an early-stage Steamflood, SPE 37564, SPE Reservoir Eng. 12, 4, 277-283. 
Wani M.R., Al-Kabli S.K. (2005) Sequence Stratigraphy and Reservoir Characterization of the 2nd Eocene dolomite Reservoir, Wafra field, Divided zone, Kuwait-Saudi Arabia, SPE 92827.

Widdel F., Rabus R. (2001) Anaerobic biodegradation of satured and aromatic hydrocarbons, Curr. Opin. Biotech. 12, 259-276.

Wilhelms A., Larter S.R., Head I., Farimond P., di-Primio R., Zwach C. (2000) Biodegradation of oil in uplifted basins prevented by deep-burial sterilisation, Nature 411, 1034-1037.

Williams L.L., William S.F., Kumar M. (2001) Effects of discontinuous shales on multi zone steam flood performance in the Kern River field, October 2001 Reservoir Evaluation and Engineering, pp. 350-357.
Winters J.C., Williams J.A. (1969) Microbial alteration of oil in reservoirs, Am. Chem. Soc. Div. Petr. Chem. Preprints 14, E22-E31.

Zhang W., Youn S., Doan Q. (2005) Understanding reservoir architectures and steam chamber growth at Christina Lake, Alberta, by using 4D seismic and crosswell seismic imaging, Paper SPE 97808 presented at the SPE/PS-CIM/CHOA International Operations and Heavy Oil Symposium, Calgary, Alberta, Canada, 1-3/11/05.

Final manuscript received in January 2008

Published online in June 2008

Copyright (c) 2008 Institut français du pétrole

Permission to make digital or hard copies of part or all of this work for personal or classroom use is granted without fee provided that copies are not made or distributed for profit or commercial advantage and that copies bear this notice and the full citation on the first page. Copyrights for components of this work owned by others than IFP must be honored. Abstracting with credit is permitted. To copy otherwise, to republish, to post on servers, or to redistribute to lists, requires prior specific permission and/or a fee: Request permission from Documentation, Institut français du pétrole, fax. +33147527078 , or revueogst@ifp.fr. 